\title{
Synthesis, inhibitory and activation properties of prenyldiphosphate mimics for aromatic prenylations with ubiA-prenyltransferase
}

\author{
Svetlana Zakharova, Michael Fulhorst, Lech Luczak, and Ludger Wessjohann* \\ Department of Bio-organic Chemistry, Leibniz-Institute of Plant Biochemistry \\ Weinberg 3, D-06120 Halle (Saale), Germany \\ E-mail: wessjohann@ipb-halle.de
}

\section{Dedicated to Prof. Dr. Karsten Krohn on the occasion of his $60^{\text {th }}$ birthday}

(received 01 Jul 04; accepted 30 Nov 04; published on the web 07 Dec 04)

\begin{abstract}
4-Hydroxybenzoate oligoprenyl transferase from E. coli (ubiA-prenyl transferase) is a crucial enzyme for ubiquinone biosynthesis. It catalyzes the formation of 3-oligoprenyl-4-hydroxybenzoates like geranyl hydroxybenzoate (GHB, 23) from geranyl pyrophosphate (GPP, 22). Several analogues and mimics of geranyl pyrophosphate have been prepared for an examination of their ability to inhibit the enzyme. 7,11-Dimethyl-3-oxododeca-6,10-dienoic acid (2), 3-hydroxy7,11-dimethyldodeca-6,10-dienoic acid (3), 2-hydroxy-4,8-dimethyl-3,7-nonadienylphosphonic acid (4), and tripotassium [[(4E)-5,9-dimethyldeca-4,8-dienyl]phosphinato](difluoro)methylphosphonate (5) were synthesized from geraniol. $\omega$-2, $\omega$-1-Dihydroxylated farnesyl diphosphate 6 was prepared from trans,trans-farnesol. All compounds were tested for enzyme inhibition in a competitive assay with natural substrate. The effect of these compounds on ubiA-prenyltransferase activity varied substantially, ranging from almost full inhibition to, surprisingly, enhanced enzymatic activity at low concentrations by some compounds. A special, EDTAmodifyable magnesium effect is discussed as potential reason.
\end{abstract}

Keywords: Prenyltransferase, geranyl diphosphate, enzyme inhibition, farnesyl transferase inhibitor, enzyme activation, magnesium ion effect

\section{Introduction}

Prenyl transferases catalyze the electrophilic alkylation of electron-rich acceptor substrates by the hydrocarbon moiety of allylic isoprenoid diphosphates. ${ }^{1}$ Some of the more common acceptors are carbon-carbon double bonds (synthesis of isoprenoid chains), aromatic rings (e.g. for the synthesis of respiratory quinones, vitamins E), ${ }^{2}$ amino groups (modification of tRNAs), ${ }^{3}$ and sulfhydryl moieties (modification of proteins such as ras-farnesyl transferase, an anti- 
proliferation target). ${ }^{4}$ The products of prenyl transfer reactions are ultimately converted into over 30000 naturally occurring isoprenoid compounds. Isoprenoid biosynthesis is essential in all organisms. In Escherichia coli, for instance, the isoprenoids ubiquinone and bactoprenol are required for respiration and cell wall biosynthesis, respectively. The aromatic polyprenyl transferase encoded by $u b i A$ is involved in the biosynthesis of prenylated quinones (Scheme 1). ${ }^{5}$ In vivo, the enzyme transfers diphosphorylated acyclic oligoprenyl moieties (diphosphorylated terpene alcohols) to the meta-position of 4-hydroxybenzoic acid (PHB). ${ }^{6}$

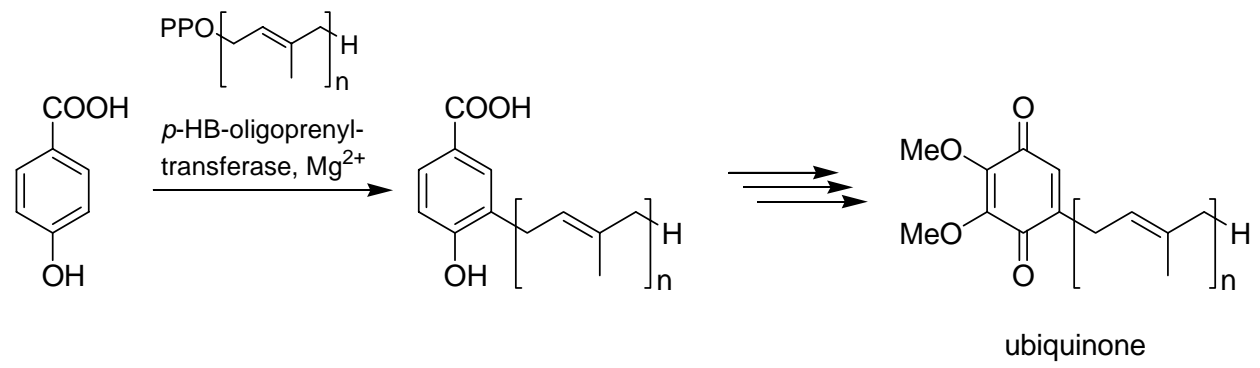

Scheme 1. Biosynthesis of ubiquinones in E. coli. (similar in other organisms).

Possible candidates for mimics of geranyl diphosphate should fulfill three requirements: they should show affinity to a prenyl diphosphate synthase or transferase; they should be stable under study conditions, especially against hydrolysis; and they should be easy to synthesize. With these requirements in mind, we approached two different classes of candidates for our approach. The first class consists of non-hydrolysable diphosphate analogues with phosphorus-based acidic moieties, the second one of mimics where all phosphates are replaced by non-phosphorus (acidic) moieties.

A natural example of the latter group is chaetomellic acid (1, Figure 1), which was isolated from the coelomycete Chaetomella acutiseta. It inhibits farnesyl-protein-transferase at IC50values in the nanomolar range. ${ }^{7}$ Chaetomellic acid is a competitor to farnesyl pyrophosphate (FPP), and does not contain any phosphate moiety.

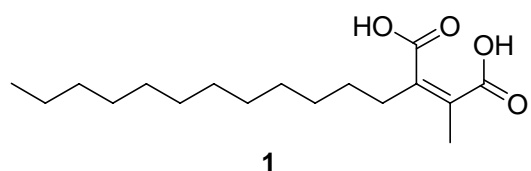

1

Figure 1. Chaetomellic acid A (1), a natural inhibitor of farnesyl-protein transferase.

We were interested in the synthesis of the similar $\beta$-keto acid $\mathbf{2}$ and $\beta$-hydroxy acid $\mathbf{3}$ which might act as competitive inhibitors of $u b i A-p$-hydroxybenzoate oligoprenyl transferase (Figure 2).

As examples of the first class, several non-hydrolysable allylic diphosphate mimics are known from the literature. These include phosphonophosphates, ${ }^{8}$ phosphonophosphinates, ${ }^{9}$ and diphosphonates, ${ }^{10}$ where the methylene group replaces the oxygen between phosphorus and 
carbon and the bridging oxygen between the two phosphorus atoms. All these phosphinates are inhibitors, but the bisphosphonates with an ester bond linked to prenyl are still enzyme cleavable and thus potential substrates. ${ }^{6 b, 11,12}$ Therefore, we excluded the latter and decided to try $\beta$-hydroxyphosphonic acid $\mathbf{4}$ as an inhibitor halfway between class I and class II. Such compounds were investigated by Kang et al. with respect to their inhibitory activity of protein farnesyltransferase. ${ }^{13}$ A pure class II substrate is the stable diphosphate analog 5. Finally, 10,11-dihydroxy-3,7,11-trimethyldodeca-2,6-dienyl diphosphate (6), i.e. oxidized FPP, was included. Although it is a hydrolysable substrate in principle, we knew from earlier experiments that it is accepted poorly by $u b i A$-transferase and thus, it may act as an inhibitor. In this report, we present the synthesis of these compounds, along with a study of their impact on the magnesium depended activity of aromatic ubiA-oligoprenyl transferase of E. coli.

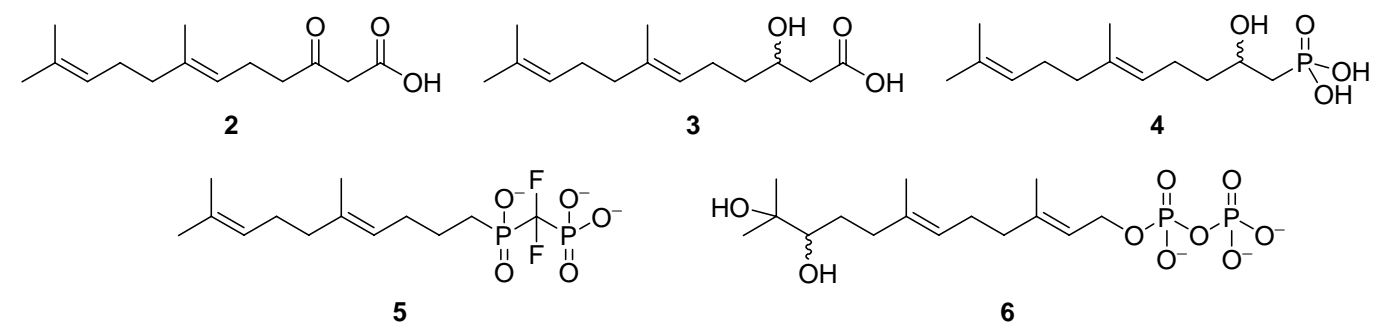

Figure 2. Potential inhibitors of prenyl transferase.

\section{Results and Discussion}

\section{Syntheses}

The synthesis of the $\beta$-keto acid 2 and $\beta$-hydroxy acid 3 is shown in Scheme 2. Methyl acetoacetate was selectively alkylated at position 4 with geranyl bromide. Treatment of the resulting $\beta$-keto ester 7 with $\mathrm{LiOH}$ in $\mathrm{THF} / \mathrm{H}_{2} \mathrm{O}$ gave the desired alkylated $\beta$-carboxylic acid 2 . Reduction of ketone 7 with $\mathrm{NaBH}_{4}$ in $\mathrm{MeOH}$ produced $\beta$-hydroxy ester 8, which upon hydrolysis with $\mathrm{LiOH}$ in $\mathrm{THF} / \mathrm{H}_{2} \mathrm{O}$ afforded the racemic $\beta$-hydroxy acid 3.

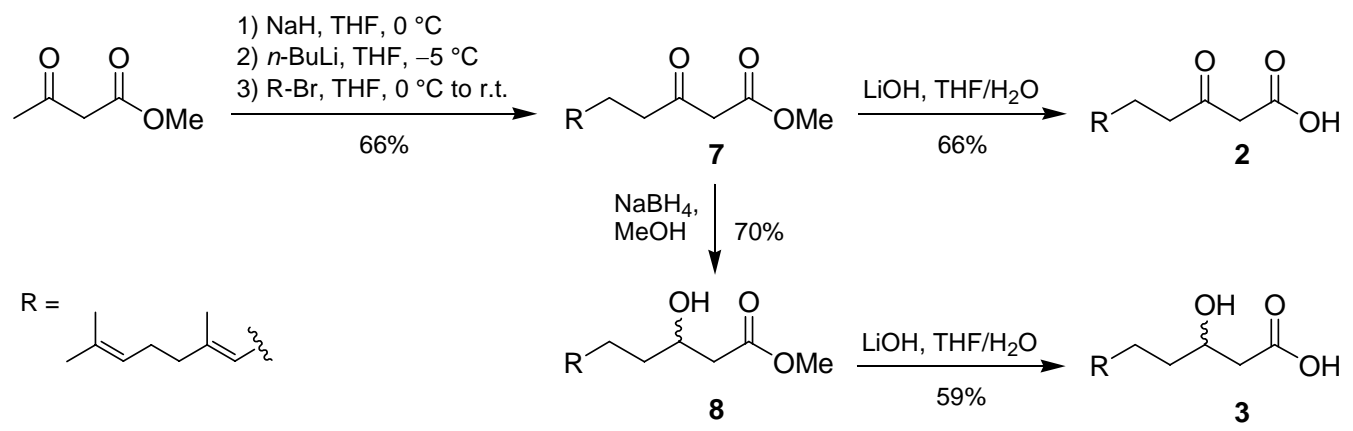

Scheme 2. Synthesis of geranyl-based $\beta$-keto carboxylic acid 2 and $\beta$-hydroxy carboxylic acid 3. 
The synthesis of the geranyl-based phosphonate 4 (Scheme 3) started with the Doering oxidation of geraniol to geranial (9), which was reacted with dimethyl methylphosphonate anion to give racemic 10. This methyl phosphonic ester was cleaved with trimethylsilyl bromide in the presence of 2,4,6-collidine as acid scavenger to afford the free hydroxyphosphonic acid $4 .{ }^{14,15}$ An attempt to oxidize $\beta$-hydroxy phosphonate 3 to the $\beta$-keto phosphonate by Doering oxidation failed.

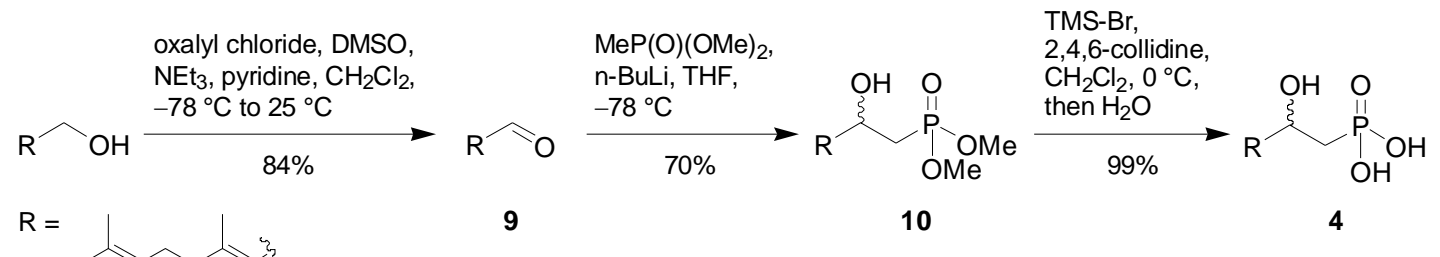

Scheme 3. Synthesis of geranyl-based $\beta$-hydroxy phosphonic acid 4.

The synthetic route to phosphonate 5 (Scheme 4), a hydrolytically stable analog of diphosphates, was identical to one known for a farnesyl derivative. ${ }^{14}$ The difluoromethylene link is a better oxygen mimic than methylene. Thus, geraniol was subjected to a standard $\mathrm{C}_{2}$-homologation to form ester $\mathbf{1 1}$, followed by ester reduction and conversion of the resulting alcohol into bromide 12. The Arbuzov reaction ${ }^{16}$ of $\mathbf{1 2}$ with excess of triethyl phosphate delivered in high yield diester 13, which by base-induced hydrolysis was converted into the mono acid. Subsequent DMF-catalyzed reaction with oxalyl chloride in benzene at room temperature afforded ethyl phosphonochloridoate 14. Treatment of the intermediate mono phosphonate with excess $N, N$-dimethylaminotrimethylsilane in dichloromethane prior to acid chloride formation resulted in a faster reaction and a cleaner transformation into ethyl phosphonochloridoate $\mathbf{1 4} .^{14,17}$ Subsequent C-P coupling reaction was performed by dropwise addition of a THF solution of 14 to a solution of the anion 15 at $-78^{\circ} \mathrm{C}$. The anion 15 was formed by the reaction of LDA with diethyl difluoromethylphosphonate. ${ }^{18}$ The resulting diester 16 was cleaved with TMS-I in the presence of 2,4,6-collidine as acid scavenger ${ }^{14}$ to produce the desired product 5 .
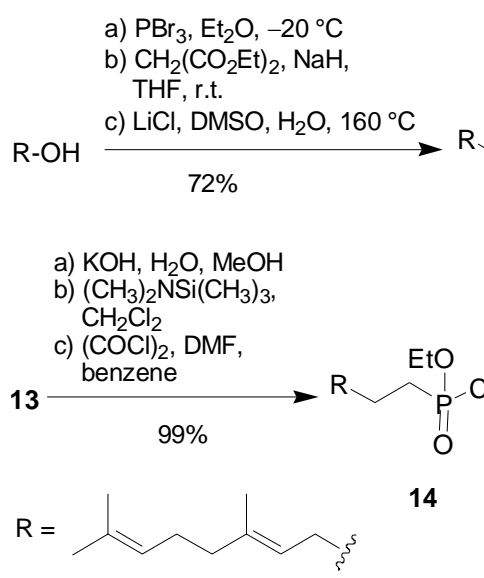

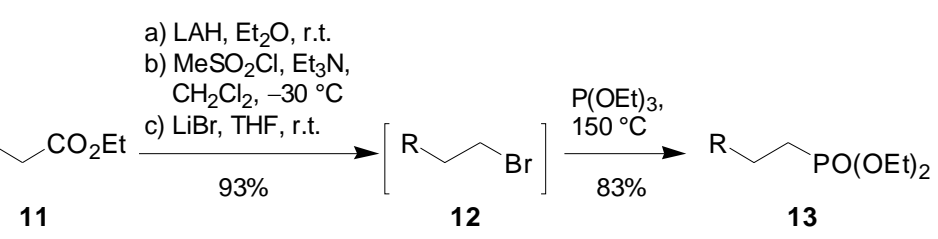

12

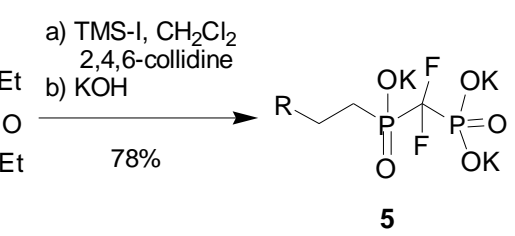

Scheme 4. Synthesis of tripotasssium phosphinato(difluoro)methylphosphonate 5. 

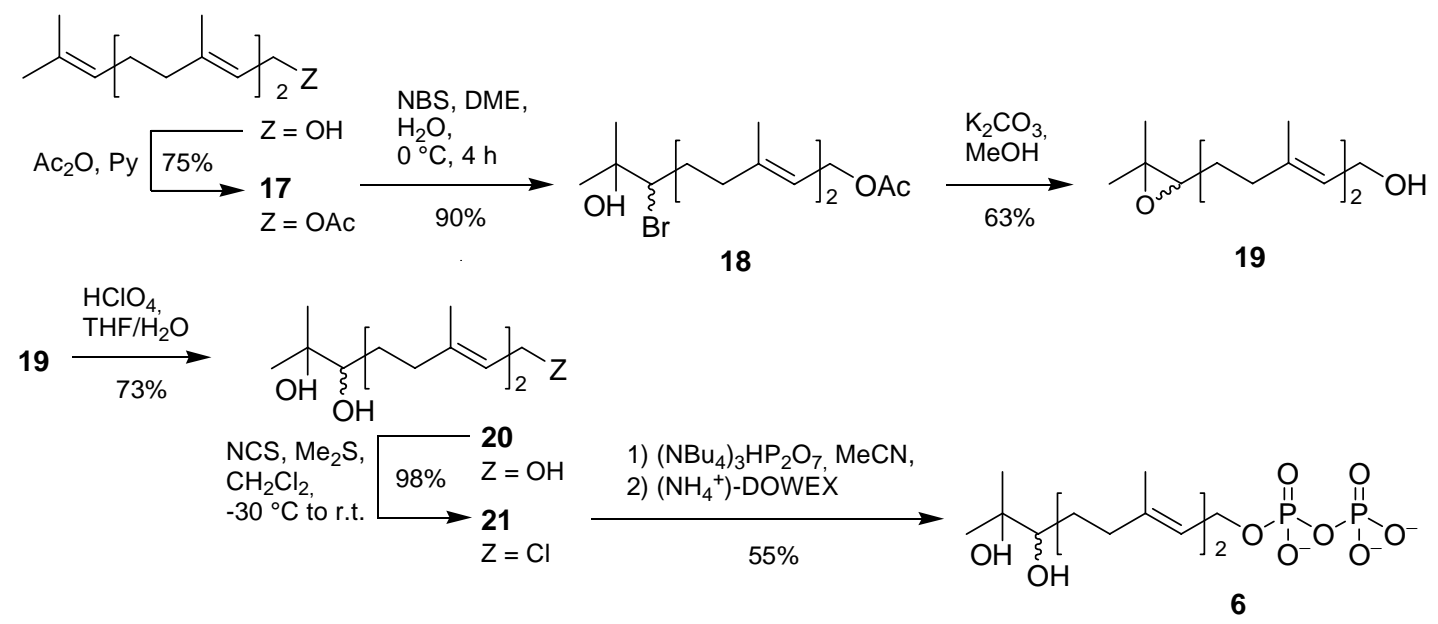

Scheme 5. Synthesis of (E,E)-10,11-dihydroxyfarnesyl diphosphate 6.

The synthesis of (E,E)-10,11-dihydroxyfarnesyl diphosphate started from all-trans farnesol (Scheme 5), protected as acetate 17. For selective epoxidation of the 10,11-double bond we followed a method developed by van Tamelen et al. ${ }^{19}$ Farnesyl acetate was treated with NBS in aqueous tert-butyl alcohol ${ }^{20}$ or aqueous 1,2-dimethoxyethane ${ }^{21}$ to give the desired bromohydrin 18 in $29 \%$ and $90 \%$ yield, respectively. Base induced the formation of epoxide $19,{ }^{21}$ which in turn, was ring-opened with aqueous perchloric acid to give triol $\mathbf{2 0}^{22}(E, E)-10,11$-Dihydroxyfarnesol 20 was converted into chloride 21, which was finally transformed into $(E, E)-10,11$-dihydroxyfarnesyl diphosphate according to Davisson et al. ${ }^{23}$

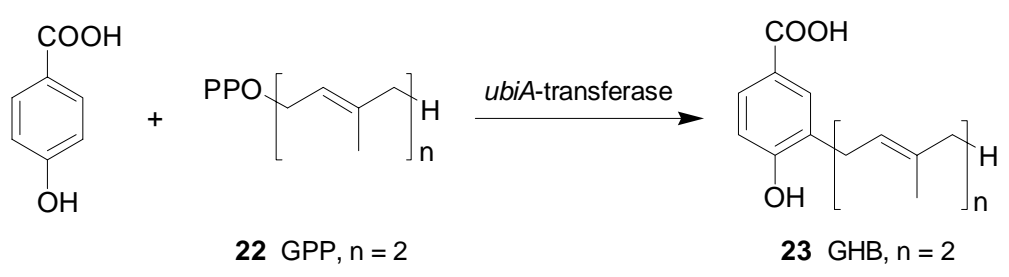

Scheme 6. Chemoenzymatic synthesis of geranyl hydroxybenzoate (GHB, 23).

\section{UbiA-Transferase inhibition}

The compounds described above were tested for their ability to inhibit $u b i A$-transferase using a membrane fraction of a cell disruption of the E. coli K12 strain pALMU3. ${ }^{24}$ Compounds were assayed in competition to $1 \mathrm{mM}$ geranyl diphosphate (GPP) at concentrations ranging up to $1 \mathrm{mM}$ (Scheme 6). These results, expressed as the geranyl hydroxylbenzoate (GHB) formation in the presence of the compound divided by the GHB formation in the absence of the compound (i.e. relative conversions) are shown in Figures 3 and 4. 


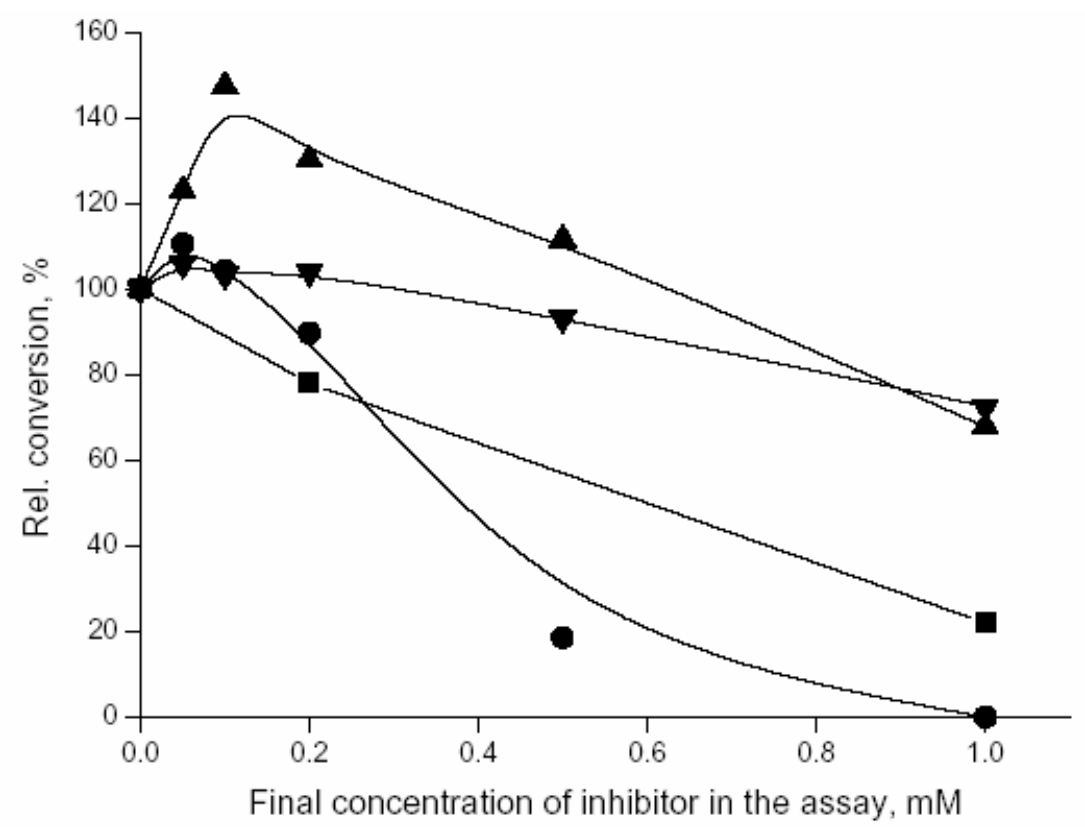

Figure 3. GHB synthesis from geranyl diphosphate as a function of inhibitor concentration: $\beta$-keto acid $\mathbf{2}(\boldsymbol{\bullet}) *$ and $\beta$-hydroxy acid $\mathbf{3}(\bullet)$, phosphinato(difluoro)methylphosphonate $\mathbf{5}(\mathbf{\Lambda})$, $(E, E)$-10,11-dihydroxyfarnesyl diphosphate $\mathbf{6}(\mathbf{\nabla})$.

* In this assay, the membrane fraction contained $32 \mathrm{mg}$ protein $/ \mathrm{mL}$, all others contained $0.67 \mathrm{mg}$ protein/mL. For standard assay conditions see Experimental Section.

Only $\beta$-hydroxy acid $\mathbf{3}$ and $\beta$-keto acid $\mathbf{2}$ showed significant inhibitory activity regarding the conversion of geranyl diphosphate (Figure 3). ${ }^{25}$ Their IC50 values are 0.36 and $0.58 \mathrm{mM}$, respectively. At $1 \mathrm{mM}$ concentration, $\beta$-hydroxy carboxylate $\mathbf{3}$ showed almost complete inhibition of ubiA-transferase activity. $\beta$-Hydroxy phosphonate (from $\mathbf{4}$, remaining activity: $90 \%$ at $1 \mathrm{mM}$, data not shown) and difluoro phosphinophosphonate $\mathbf{5}$ did not show significant inhibitory activity. Although these molecules are structurally more related to the natural substrate than the carboxylic acids, the lower binding affinities have been attributed to differences in the $\mathrm{p} K_{\mathrm{a}}$ of the phosphate versus the phosphonate groups. ${ }^{26}$ Difluoromethylene analogues more closely match the $\mathrm{p} K_{\mathrm{a}}$, but the fluorine atoms introduce steric interactions and other properties not found in the natural diphosphate substrates. ${ }^{26}$ Another reason for the low activity of $\mathbf{4}$ and $\mathbf{5}$ might be the structural difference compared to the natural substrates because in $\mathbf{4}$ the distance of the diphosphate mimicking moiety to the first double bond is shorter, in $\mathbf{5}$ it is longer by one atom than in natural oligoprenyl diphosphates.

$(E, E)-10,11$-Dihydroxyfarnesyl diphosphate $\mathbf{6}$ is only very poorly accepted as substrate, although sterically it must be acceptable to the enzyme as has been shown by us before in a substrate model. ${ }^{12}$ Surprisingly, under standard conditions as described above, its inhibitory effect is very weak too. 
An interesting pattern was seen for inhibitors $\mathbf{3}$ and 5. Before exerting inhibitory activity, their addition initially leads to enhanced conversion, i.e. they act as activators. This effect is dependent on the concentration not only of the inhibitor but also of the enzyme concentration (Figure 4). $\beta$-Hydroxy acid $\mathbf{3}$ is a potent inhibitor with a biocatalyst membrane fraction containing $0.67 \mathrm{mg}$ protein $/ \mathrm{mL}$. After an initial $10 \%$ increase in activity at $0.05 \mathrm{mM}$ concentration (vide infra) inhibitory properties prevail and at $1 \mathrm{mM}$ concentration of $\mathbf{3}$, enzyme activity is almost $0 \%$. In the case of compound $\mathbf{5}$ the activation effect is even larger and up to $47 \%$ increase of activity at $0.1 \mathrm{mM}$ concentration is observed at low enzyme concentration.

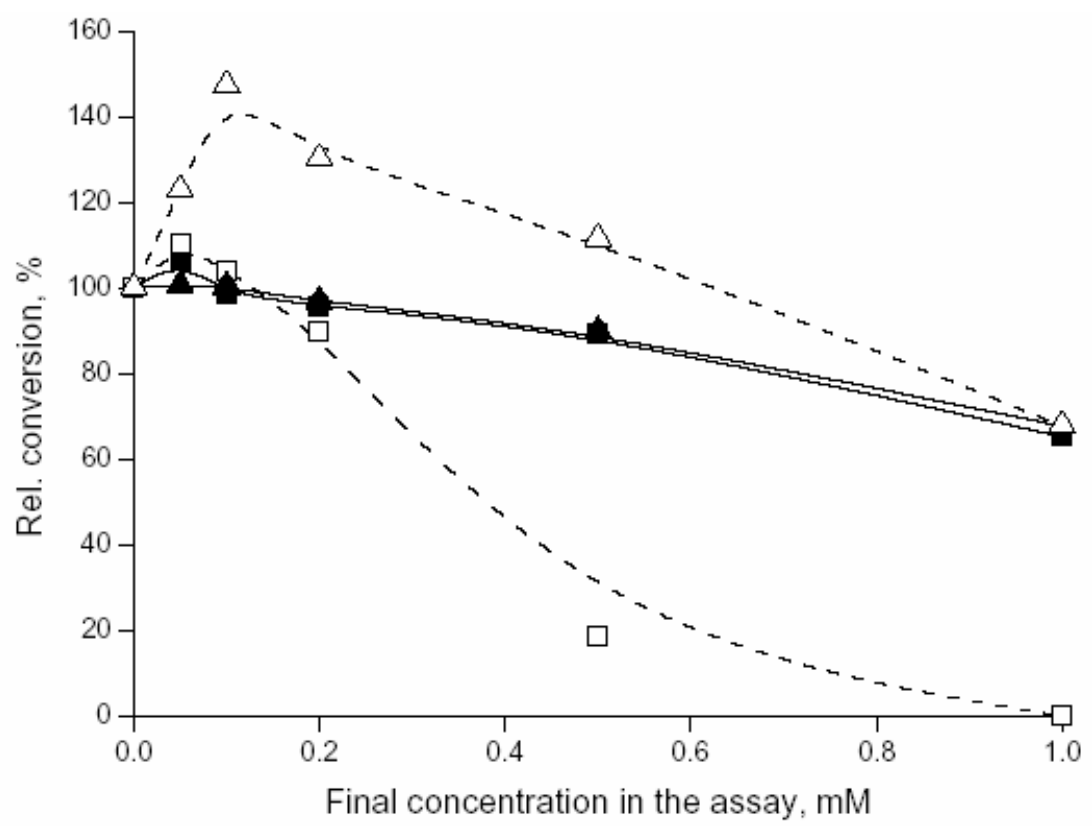

Figure 4. GHB synthesis from geranyl diphosphate as a function of inhibitor and enzyme concentration. The results for $\beta$-hydroxy carboxylate $\mathbf{3}(\mathbf{\square}, \square)$ and for phosphinato(difluoro)methylphosphonate $\mathbf{5}(\boldsymbol{\Delta}, \triangle)$ are shown with squares and triangles, respectively. Empty data points $\square, \triangle$ : the membrane fraction contained $0.67 \mathrm{mg}$ protein $/ \mathrm{mL}$; filled data points $\boldsymbol{\square}, \boldsymbol{\Delta}$ : the membrane fraction contained $2.68 \mathrm{mg}$ protein $/ \mathrm{mL}$. For standard assay conditions see Experimental Section.

From our earlier experiments we know that even a small reduction in the concentration of the magnesium ions results in an increase of product formation (through enhanced enzyme stability). ${ }^{6 b, 27}$ Although elevated concentrations of magnesium ions ensure a high initial rate of the enzymatic reaction, they cause the enzyme denaturation much faster then in experiments where the $\mathrm{MgCl}_{2}$ concentration is reduced. Thus, high salt concentration ultimately results in lower turnover. We suppose that the dual role played by $\mathrm{MgCl}_{2}$ is particularly responsible for the increased enzymatic activity observed with small amounts of inhibitor. Because the tested inhibitors are diphosphate mimics, they are also able to form complexes with $\mathrm{Mg}^{2+}$-ions. Due to 
this complexation, especially with phosphinato(difluoro)methylphosphonate 5, an activity increase up to $47 \%$ was observed. In order to prove this hypothesis, an alternative $\mathrm{Mg}^{2+}$ scavenger, which should not have any inhibitory activity, was applied to the system. Indeed, experiments with ethylenediaminetetraacetic acid (EDTA) led to an enhancement of activity, similar in concentration dependence as observed before, but without any inhibition of the enzyme at higher concentrations (Figure 5).

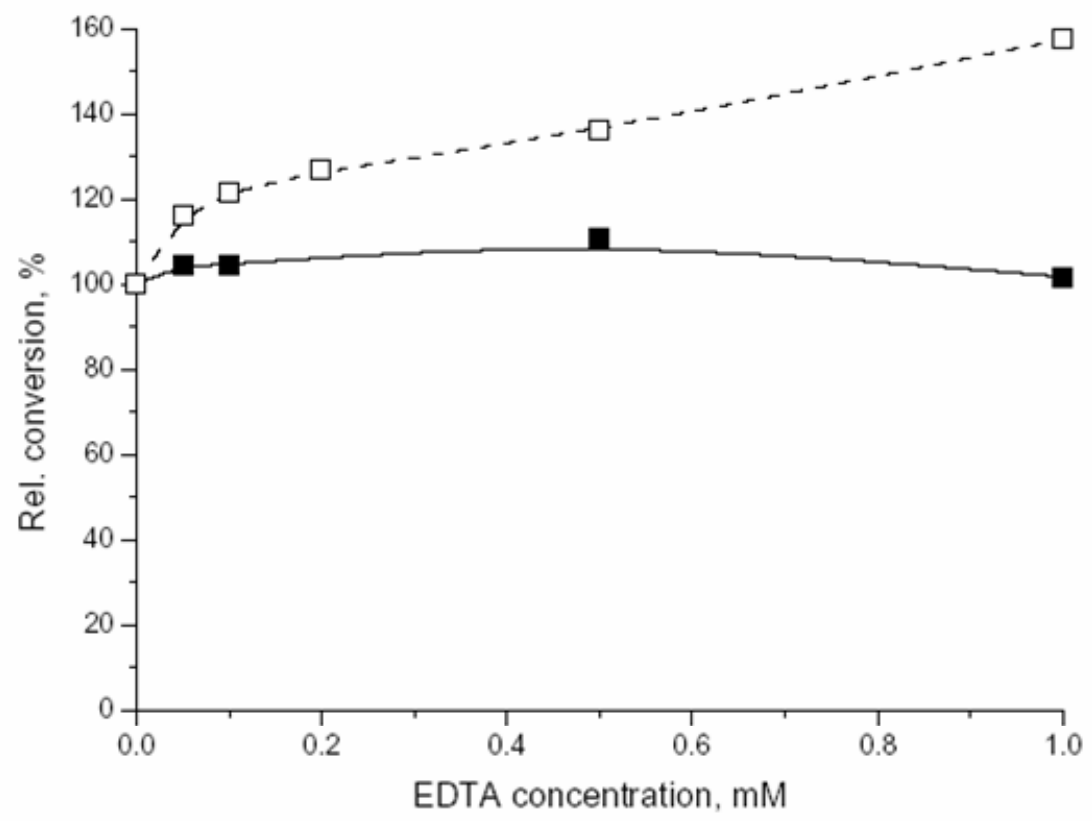

Figure 5. GHB synthesis from geranyl diphosphate as a function of EDTA concentration $\left(\mathrm{Mg}^{2+}-\right.$ complex formation). $\square$ : Membrane fraction with $0.67 \mathrm{mg}$ protein $/ \mathrm{mL}$; $\mathbf{m}$ : membrane fraction with $2.68 \mathrm{mg}$ protein $/ \mathrm{mL}$. For standard assay conditions see Experimental Section.

Of course, such an effect is more evident at low enzyme concentration, i.e. in systems where the $\mathrm{Mg}^{2+}$-concentration relative to that of the enzyme is high; thus $[\mathrm{Mg}]^{2+}$ reduction results in a higher effect. Thus, the different activation/inhibition profiles of the compounds $\mathbf{2}-\mathbf{6}$, displayed e.g. in Figure 3, result from an overlap of several contrasting effects: a competitive inhibition at the enzyme, the magnesium ion binding properties of inhibitor vs. GPP vs. enzyme, and a resultant irreversible influence on a (concentration dependent) enzymatic activity.

In summary, the different substances described show varied effects on $u b i A$-transferase. For all compounds, a very slightly to significantly increased enzymatic activity was observed at low concentration. This can be attributed to the $\mathrm{Mg}^{2+}$-complexating activity inherent to diphosphate mimics. At higher concentrations this positive effect is overruled by the inhibitory activity. The two best inhibitors were the $\beta$-oxidized carboxylic acids $\mathbf{2}$ and $\mathbf{3}$, the latter is clearly superior. $\beta$-Keto acids like $\mathbf{2}$ may act in their enol form and thus may also be considered as $\beta$-hydroxy 
carboxylates, although with less degree of freedom. These observations guide the way to improved inhibitors in the future.

\section{Experimental Section}

General Procedures. ${ }^{1} \mathrm{H}$ and ${ }^{13} \mathrm{C}$ NMR spectra were recorded on a Varian Mercury 300 and a Varian Mercury 400 instrument using $\mathrm{CDCl}_{3}$ as a solvent (unless noted otherwise) and $\left(\mathrm{CH}_{3}\right)_{4} \mathrm{Si}$ or $\mathrm{CDCl}_{3}\left({ }^{13} \mathrm{C}, \delta 77.00\right)$ as internal standards. ${ }^{31} \mathrm{P}$ and ${ }^{19} \mathrm{~F}$ NMR spectra were recorded on a Varian Mercury 400. ${ }^{31} \mathrm{P}$ Chemical shifts are reported in ppm relative to an external standard of $85 \% \mathrm{H}_{3} \mathrm{PO}_{4}$. Non-quantitative measurements were performed in the hydrogen decoupled modus; quantitative measurements were performed in the hydrogen-coupled modus. A known volume of an aqueous solution of diammonium phenylphosphonate $(1.0 \mathrm{M})$ was added to the samples as a quantitative internal standard. ${ }^{19} \mathrm{~F}$ data were obtained using $\mathrm{CFCl}_{3}$ as an external reference. Ion electrospray ionization (ESI) mass spectra were recorded on a Finnigan MAT TSQ 7000 or with a API 150Ex (Applied Biosystems) equipped with a turbo ionspray source. High-resolution ESI mass spectra were recorded on a Bruker 70e FT-ICR (Bruker Daltonics, USA) using nitrogen as drying gas at $150{ }^{\circ} \mathrm{C}$. IR spectra were measured on a Bruker IFS 28 as thin oil films between $\mathrm{KCl}$ plates or as $\mathrm{KBr}$ pellets. HPLC was performed on a HP 1090 with integrated photo diode array detector (Multosphere 100-5 $\mu \mathrm{m}$ RP 18) or a Merck D-7000 (Lichrosphere 100-5 $\mu \mathrm{m}$ RP 18). Samples were chromatographed with methanol/water mixtures containing $0.2 \%$ formic acid 80:20, flow rate: $1 \mathrm{~mL} / \mathrm{min}$.

Tetrahydrofuran and diethyl ether were freshly distilled from sodium/benzophenone, dichloromethane was freshly distilled from calcium hydride. Other solvents and chemicals obtained from commercial sources were used without further purification. All moisture and air sensitive reactions were conducted under argon in vacuum-dried glassware. Flash column chromatography was carried out on silica [Merck: Kieselgel 60, particle size 0.040-0.063 mm (230-240 Mesh ASTM), Art.-No. 9385, Baker: silica for flash chromatography, particle size 0.030-0.060 mm, Art.-No. 7024-02] under a pressure of 1.4-1.6 bar. Thinlayer-chromatography was performed using silica plates from Merck (Kieselgel-60 $\mathrm{F}_{254}$ on aluminum sheets with fluorescence indicator, Prod.-No. 5554).

(6E)-7,11-Dimethyl-3-oxododeca-6,10-dienoic acid (2). ${ }^{28}$ To a solution of ester 7 (0.5 g, $1.9 \mathrm{mmol})$ in $\mathrm{THF} / \mathrm{H}_{2} \mathrm{O}(3: 1,4 \mathrm{~mL})$ was added lithium hydroxide $(0.42 \mathrm{~g}, 9.9 \mathrm{mmol})$, and the mixture was stirred over night at room temperature, acidified with $1 \mathrm{M}$ hydrochloric acid and then extracted with ether $(50 \mathrm{~mL})$. The organic layer was washed with water $(2 \times 30 \mathrm{~mL})$ and brine $(30 \mathrm{~mL})$, dried $\left(\mathrm{Na}_{2} \mathrm{SO}_{4}\right)$ and concentrated to give $2(0.31 \mathrm{~g}, 66 \%)$ as a yellow oil. ${ }^{1} \mathrm{H} \mathrm{NMR}$ $\left(300 \mathrm{MHz}, \mathrm{CDCl}_{3}\right): \delta 5.07(\mathrm{dd}, J=1.1,6.9 \mathrm{~Hz}, 2 \mathrm{H}), 3.76-3.72(\mathrm{~m}, 2 \mathrm{H}), 3.53-3.45(\mathrm{~m}, 2 \mathrm{H})$, 2.56-2.44 (m, 1H), 2.33-2.14 (m, 2H), 2.03-2.94 (m, 2H), 1.88-1.83 (m, 1H), $1.67(\mathrm{~s}, 3 \mathrm{H}), 1.59$ $(\mathrm{s}, 3 \mathrm{H}), 1.56(\mathrm{~s}, 3 \mathrm{H}) ;{ }^{13} \mathrm{C} \mathrm{NMR}\left(75.5 \mathrm{MHz}, \mathrm{CDCl}_{3}\right): \delta 208.7,167.4,136.7,136.2,123.9,121.8$, 
49.1, 43.1, 39.6, 26.6, 25.7, 22.2, 17.7, 16.1. MS (APCI) (negative mode): $\mathrm{m} / \mathrm{z} 237$ [M-H] ${ }^{-}$IR (film): $\widetilde{v} 3446$ (bs), 2966, 2925, 2856 (sh), 1743, 1717, 1437, 1375, 1319, 1237, 1158, $1118 \mathrm{~cm}^{-1}$. (6E)-3-Hydroxy-7,11-dimethyldodeca-6,10-dienoic acid (3). To a solution of ester 8 (0.29 g, $1.1 \mathrm{mmol})$ in $\mathrm{THF} / \mathrm{H}_{2} \mathrm{O}(2: 1,3 \mathrm{~mL})$ was added lithium hydroxide $(92 \mathrm{mg}, 2.2 \mathrm{mmol})$. After stirring at room temperature for $2 \mathrm{~h}$ were added ether $(50 \mathrm{~mL})$ and $1 \mathrm{M}$ hydrochloric acid $(30 \mathrm{~mL})$. The organic layer was separated, washed with $\mathrm{H}_{2} \mathrm{O}(30 \mathrm{~mL})$, dried $\left(\mathrm{Na}_{2} \mathrm{SO}_{4}\right)$ and concentrated to give carboxylic acid $3(0.16 \mathrm{~g}, 59 \%)$ as a pale yellow oil. ${ }^{1} \mathrm{H} \mathrm{NMR}\left(300 \mathrm{MHz}, \mathrm{CDCl}_{3}\right): \delta 5.78$ (bs, OH), 5.16-5.05 (m, 2H), 4.06-4.01 (m, 1H), $2.57(\mathrm{dd}, J=3.3,16.5 \mathrm{~Hz}, 1 \mathrm{H}), 2.47(\mathrm{dd}, J=$ 8.8, 16.5 Hz, 1H), 2.13-1.97 (m, 6H), $1.68(\mathrm{~s}, 3 \mathrm{H}), 1.62(\mathrm{~s}, 3 \mathrm{H}), 1.60(\mathrm{~s}, 3 \mathrm{H})$, v1.55-1.43 (m, $2 \mathrm{H}) ;{ }^{13} \mathrm{C}$ NMR $\left(75.5 \mathrm{MHz}, \mathrm{CDCl}_{3}\right): \delta 177.0,135.9,131.2,124.1,123.5,67.6,41.1,39.7,36.4$, 26.4, 25.8, 24.2, 17.8, 16.1. MS (ESI): $\mathrm{m} / \mathrm{z}$ (negative mode) 239 [M-H] $]^{-}$IR (film): $\widetilde{v} 3419$ (bs), 2966, 2924, 2857 (bs), 1716 (s), 1436, 1375, 1297, 1182, 1105, 1069, 983 (sh) cm . $^{-1}$ Anal. Calcd for $\mathrm{C}_{14} \mathrm{H}_{24} \mathrm{O}_{3}$ : C, 69.96; H, 10.07. Found: C, 69.98; $\mathrm{H}, 10.27$.

(3E)-2-Hydroxy-4,8-dimethylnona-3,7-dienylphosphonic acid (4). To a solution of phosphonate $10(0.61 \mathrm{~g}, 2.3 \mathrm{mmol})$ and 2,4,6-collidine $(0.84 \mathrm{~mL}, 6.5 \mathrm{mmol})$ in dichloromethane $(20 \mathrm{~mL})$ at $0{ }^{\circ} \mathrm{C}$ was added TMSBr $(0.84 \mathrm{~mL}, 6.5 \mathrm{mmol})$ via syringe. After stirring at $0{ }^{\circ} \mathrm{C}$ for $30 \mathrm{~min}$, the cooling bath was removed and stirring was continued for $6 \mathrm{~h}$. Then the reaction was quenched by addition of $2 \mathrm{~N}$ hydrochloric acid $(10 \mathrm{~mL})$. The aqueous phase was extracted with ether $(2 \mathrm{x}$ $20 \mathrm{~mL}$ ) and the organic layers were combined. The organic phase was washed with $2 \mathrm{~N}$ hydrochloric acid $(2 \times 10 \mathrm{~mL})$, water $(10 \mathrm{~mL})$ and brine $(10 \mathrm{~mL})$, dried $\left(\mathrm{Na}_{2} \mathrm{SO}_{4}\right)$ and concentrated to yield $4(0.54 \mathrm{~g}, 99 \%)$ as a white solid. ${ }^{1} \mathrm{H}$ NMR $\left(300 \mathrm{MHz}, \mathrm{D}_{2} \mathrm{O}\right): \delta 5.46-5.44$ $(\mathrm{m}, 1 \mathrm{H}), 5.03-5.00(\mathrm{~m}, 1 \mathrm{H}), 3.79(\mathrm{~s}, 1 \mathrm{H}), 2.21-2.13(\mathrm{~m}, 1 \mathrm{H}), 1.95-1.76(\mathrm{~m}, 3 \mathrm{H}), 1.51(\mathrm{~s}, 3 \mathrm{H})$, $1.49(\mathrm{~s}, 3 \mathrm{H}), 1.42(\mathrm{~s}, 3 \mathrm{H}) ;{ }^{13} \mathrm{C} \mathrm{NMR}\left(75 \mathrm{MHz}, \mathrm{D}_{2} \mathrm{O}\right): \delta 140.1,134.4,128.4,125.0,65.8,39.6$, 25.9, 21.9, 18.0, 16.8. MS (ESI) (negative mode): m/z $247[\mathrm{M}-\mathrm{H}]^{-}$; MS (HR) calculated for $\mathrm{C}_{11} \mathrm{H}_{21} \mathrm{O}_{4} \mathrm{P}^{-}\left([\mathrm{M}-\mathrm{H}]^{-}\right): 247.10992$; found: 247.11046 .

Tripotassium [(4E)-5,9-dimethyldeca-4,8-dienyl]phosphinato](difluoro)methylphosphonate (5). To a solution of $16(0.24 \mathrm{~g}, 0.54 \mathrm{mmol})$ in dry dichloromethane $(3 \mathrm{~mL})$ under argon were added 2,4,6-collidine $(0.24 \mathrm{~mL}, 1.82 \mathrm{mmol})$ followed by iodotrimethylsilane $(0.50 \mathrm{~mL}$, $3.81 \mathrm{mmol}$ ) at $0{ }^{\circ} \mathrm{C}$ drop-wise over $5 \mathrm{~min}$. The reaction was stirred at $0{ }^{\circ} \mathrm{C}$ for $3 \mathrm{~h}$, the solvent was evaporated and the residue was evacuated under vacuum. Aqueous $2 \mathrm{M} \mathrm{KOH}(2 \mathrm{~mL})$ was added, and the resulting solution was extracted with ether $(3 \times 5 \mathrm{~mL})$. The aqueous phase was freeze-dried and the organic compound was extracted with methanol $(3 \times 5 \mathrm{~mL})$. The solvent was evaporated to produce $5(0.14 \mathrm{~g}, 78 \%)$ as a white, amorphous powder. ${ }^{1} \mathrm{H} \mathrm{NMR} \mathrm{(300} \mathrm{MHz,}$ $\left.\mathrm{D}_{2} \mathrm{O}\right): \delta 5.32-5.18(\mathrm{~m}, 2 \mathrm{H}), 2.18-2.02(\mathrm{~m}, 6 \mathrm{H}), 1.88-1.73(\mathrm{~m}, 2 \mathrm{H}), 1.69(\mathrm{~s}, 3 \mathrm{H}), 1.66-1.54(\mathrm{~m}$, 2H), $1.63(\mathrm{~s}, 6 \mathrm{H}) ;{ }^{13} \mathrm{C} \mathrm{NMR}\left(75.5 \mathrm{MHz}, \mathrm{D}_{2} \mathrm{O}\right): \delta 137.9,134.5,125.4,125.3,122.8$ (tdd, not all signals were found), 39.95, $30.4(\mathrm{~d}, J=15.1 \mathrm{~Hz}), 28.3(\mathrm{~d}, J=94.4 \mathrm{~Hz}), 26.9,25.9,22.1(\mathrm{~d}, J=$ $5.3 \mathrm{~Hz}), 18.1,16.5 ;{ }^{31} \mathrm{P}\left(161.9 \mathrm{MHz}, \mathrm{D}_{2} \mathrm{O}\right): \delta 34.3(\mathrm{td}, J=46.5,76.4 \mathrm{~Hz}), 4.8(\mathrm{td}, J=46.5$, $73.6 \mathrm{~Hz}$ ); ${ }^{19} \mathrm{~F}\left(376.3 \mathrm{MHz}, \mathrm{D}_{2} \mathrm{O}\right): \delta-121.4(\mathrm{dd}, J=73.6,76.4 \mathrm{~Hz})$. MS (ESI): $\mathrm{m} / \mathrm{z}$ (negative mode) $359[\mathrm{M}-\mathrm{H}]^{-}$; $\mathrm{MS}$ (HR) calculated for $\mathrm{C}_{13} \mathrm{H}_{23} \mathrm{~F}_{2} \mathrm{O}_{23} \mathrm{P}_{2}\left([\mathrm{M}-\mathrm{H}]^{-}\right)$: 359.0994; found: 359.1004. 
Ammonium (2E,6E)-10,11-dihydroxy-3,7,11-trimethyldodeca-2,6-dienyl diphosphate (6). A solution of chloride $21(0.16 \mathrm{~g}, 0.57 \mathrm{mmol})$ in acetonitrile $(2 \mathrm{~mL})$ was treated with a solution of tri-(tetrabutylammonium) hydrogen diphosphate $(1.03 \mathrm{~g}, 1.15 \mathrm{mmol})$ in acetonitrile $(1.5 \mathrm{~mL})$. After stirring at room temperature for $2 \mathrm{~h}$, the solvent was removed by rotary evaporation, and the residue was dissolved in isopropyl alcohol / $25 \mathrm{mM}$ ammonium bicarbonate (ion-exchange buffer) $(1: 49 ; \mathrm{v} / \mathrm{v})$. The slightly yellow solution was slowly passed through a column containing 30 equiv of DOWEX AG 50W-X8 cation-exchange resin (ammonium form, 100-200 mesh) that had been equilibrated before with 2 column volumes of ion-exchange buffer. The column was eluted with 2 column volumes of the same buffer at a flow rate of 1 column volume $/ 15 \mathrm{~min}$. The eluent was lyophilized to dryness to yield a fluffy white solid 6 (0.37 g, max. $0.57 \mathrm{mmol})$ containing residual ammonium carbonate buffer. The organic diphosphate content was determined by quantitative ${ }^{31} \mathrm{P}$ NMR vs. ammonium phenylphosphonate as quantitative internal standard. ${ }^{12,18}{ }^{1} \mathrm{H}$ NMR $\left(300 \mathrm{MHz}, \mathrm{D}_{2} \mathrm{O}\right): \delta 5.43(\mathrm{t}, J=6.6 \mathrm{~Hz}, 1 \mathrm{H}), 5.23(\mathrm{t}, J=6.3 \mathrm{~Hz}, 1 \mathrm{H}), 4.44$ $(\mathrm{t}, J=6.6 \mathrm{~Hz}, 2 \mathrm{H}), 3.29$ (d, $J=9.3 \mathrm{~Hz}, 1 \mathrm{H}), 2.23-1.95(\mathrm{~m}, 6 \mathrm{H}), 1.69$ (s, 3H), 1.59 (s, 3H), 1.39$1.03(\mathrm{~m}, 2 \mathrm{H}), 1.12(\mathrm{~s}, 6 \mathrm{H}) ;{ }^{13} \mathrm{C}$ NMR $\left(75.5 \mathrm{MHz}, \mathrm{D}_{2} \mathrm{O}\right): \delta 143.6,136.9,125.4,120.6,78.2,74.4$, $63.5(\mathrm{~d}, J=4.5 \mathrm{~Hz}), 39.8,36.8,29.9,26.6,25.2,24.4,16.7,16.2 ;{ }^{31} \mathrm{P} \mathrm{NMR}\left(166 \mathrm{MHz}, \mathrm{D}_{2} \mathrm{O}\right): \delta-5.8$ $(\mathrm{d}, J=21.6 \mathrm{~Hz}),-9.4(\mathrm{~d}, J=21.6 \mathrm{~Hz})$. MS (HR) calculated for $\mathrm{C}_{15} \mathrm{H}_{29} \mathrm{O}_{9} \mathrm{P}_{2}^{-}\left([\mathrm{M}-\mathrm{H}]^{-}\right)$: 415.12868; found 415.12922.

Methyl (6E)-7,11-dimethyl-3-oxododeca-6,10-dienoate (7). A suspension of $\mathrm{NaH}(0.75 \mathrm{~g}, 60 \%$ suspension in mineral oil, $18.7 \mathrm{mmol})$ in THF $(50 \mathrm{~mL})$ was cooled to $0{ }^{\circ} \mathrm{C}$, and a solution of methyl acetoacetate $(2 \mathrm{~g}, 17 \mathrm{mmol})$ in THF $(5 \mathrm{~mL})$ was added dropwise. The mixture was stirred at $0{ }^{\circ} \mathrm{C}$ for $1 \mathrm{~h}$. Then $n$-BuLi $(11.7 \mathrm{~mL}, 1.6 \mathrm{M}$ solution in THF, $18.7 \mathrm{mmol})$ was added dropwise at $-5{ }^{\circ} \mathrm{C}$. The mixture was stirred for $1 \mathrm{~h}$ while warming to room temperature and was subsequently cooled to $0{ }^{\circ} \mathrm{C}$. Subsequently, a solution of geranyl bromide $(1.84 \mathrm{~g}, 8.5 \mathrm{mmol})$ in THF ( $5 \mathrm{~mL}$ ) was added dropwise. After stirring the mixture at room temperature for $3.5 \mathrm{~h}$ saturated aqueous $\mathrm{NH}_{4} \mathrm{Cl}$ solution $(20 \mathrm{~mL})$ was added. The aqueous layer was extracted with ether $(3 \times 50 \mathrm{~mL})$ and the organic layers were combined. The organic phase was washed with water $(40 \mathrm{~mL})$ and brine $(40 \mathrm{~mL})$, dried $\left(\mathrm{Na}_{2} \mathrm{SO}_{4}\right)$ and concentrated. Flash chromatography (petroleum ether/ethyl acetate, 5:1) provided $7(1.42 \mathrm{~g}, 66 \%)$ as a pale yellow oil. ${ }^{1} \mathrm{H}$ NMR $\left(300 \mathrm{MHz}, \mathrm{CDCl}_{3}\right): \delta 5.09-5.04(\mathrm{~m}, 2 \mathrm{H}), 3.74(\mathrm{~s}, 3 \mathrm{H}), 3.44(\mathrm{~s}, 2 \mathrm{H}), 2.59-2.53(\mathrm{~m}, 2 \mathrm{H}), 2.33-$ $2.24(\mathrm{~m}, 2 \mathrm{H}), 2.06-1.96(\mathrm{~m}, 4 \mathrm{H}), 1.68(\mathrm{~s}, 3 \mathrm{H}), 1.61(\mathrm{~s}, 3 \mathrm{H}), 1.59(\mathrm{~s}, 3 \mathrm{H}) ;{ }^{13} \mathrm{C} \mathrm{NMR}(75.5 \mathrm{MHz}$, $\left.\mathrm{CDCl}_{3}\right): \delta 202.2,167.4,136.5,131.3,123.9,121.8,52.3,49.1,43.1,39.7,26.6,25.7,17.7,16.1$. MS (EI): m/z (\%) 252 (3) [M] $]^{+}, 234$ (8), 219 (10), 209 (20), 191 (63), 177 (30), 161 (20), 151 (30), 136 (68), 129 (43), 123 (55), 121 (62), 110 (53), 109 (100), 105 (83), 101 (75), 93 (57), 81 (85), 69 (97), 67 (71), 59 (70); IR (film): $\widetilde{v} 2935$ (s), 2920 (s), 2870 (sh), 1749 (s), 1700 (s), 1625 (s), 1620 (sh), 1429 (s), 1375 (w), 1300 (w), 1230 (w), 1130 (w) $\mathrm{cm}^{-1}$.

Methyl (6E)-3-hydroxy-7,11-dimethyldodeca-6,10-dienoate (8). To a solution of compound 7 $(0.5 \mathrm{~g}, 1.9 \mathrm{mmol})$ in methanol $(5 \mathrm{~mL})$ was added sodium borohydride $(0.22 \mathrm{~g}, 5.7 \mathrm{mmol})$. The mixture was stirred overnight at room temperature, and the reaction was quenched by addition of water $(2 \mathrm{~mL})$. The product was extracted with ether $(3 \times 20 \mathrm{~mL})$, and the combined organic 
phase was washed with brine $(20 \mathrm{~mL})$, dried $\left(\mathrm{Na}_{2} \mathrm{SO}_{4}\right)$ and concentrated to give $\beta$-hydroxy ester $8(0.35 \mathrm{~g}, 70 \%)$ as a colorless oil. $\mathrm{R}_{f}=0.45$ (petroleum ether/ethyl acetate 5:2). ${ }^{1} \mathrm{H}-\mathrm{NMR}$ $\left(300 \mathrm{MHz}, \mathrm{CDCl}_{3}\right): \delta 5.14-5.05(\mathrm{~m}, 2 \mathrm{H}), 2.52(\mathrm{dd}, J=3.3 \mathrm{~Hz}, J=16.5 \mathrm{~Hz}, 1 \mathrm{H}), 2.42(\mathrm{dd}, J=$ $8.8 \mathrm{~Hz}, J=16.5 \mathrm{~Hz}, 1 \mathrm{H}), 2.17-1.96(\mathrm{~m}, 6 \mathrm{H}), 1.68(\mathrm{~s}, 3 \mathrm{H}), 1.62(\mathrm{~s}, 3 \mathrm{H}), 1.59(\mathrm{~s}, 3 \mathrm{H}) ;{ }^{13} \mathrm{C} \mathrm{NMR}$ $\left(75.5 \mathrm{MHz}, \mathrm{CDCl}_{3}\right): \delta 173.2(\mathrm{C}), 135.8(\mathrm{C}), 131.3(\mathrm{C}), 124.1(\mathrm{CH}), 123.4(\mathrm{CH}), 67.6(\mathrm{CH}), 51.8$ $\left(\mathrm{CH}_{3}\right), 41.2\left(\mathrm{CH}_{2}\right), 39.7\left(\mathrm{CH}_{2}\right), 36.5\left(\mathrm{CH}_{2}\right), 26.7\left(\mathrm{CH}_{2}\right), 25.8\left(\mathrm{CH}_{3}\right), 24.0(\mathrm{CH}), 17.8\left(\mathrm{CH}_{3}\right), 16.1$ $\left(\mathrm{CH}_{3}\right)$. MS (EI): m/z (\%) 254 (3) [M] $]^{+}, 236(20)\left[\mathrm{M}-\mathrm{H}_{2} \mathrm{O}\right]^{+}, 221$ (5), 211 (35), 193 (40), 179 (28), 167 (18), 161 (30), 153 (20), 147 (28), 135 (48), 129 (39), 119 (39), 111 (42), 107 (100), 103 (40), 93 (100), 81 (36), 69 (100), 55 (38). IR (film): $\widetilde{v}$ 3425, 2922, 2890 (sh), 1740 (s), 1437, $1382,1339,1285,1198,1150,1056,933,886,818 \mathrm{~cm}^{-1}$.

(2E)-3,7-Dimethylocta-2,6-dienal (9). ${ }^{29}$ Oxalyl chloride $(4.52 \mathrm{~g}, 35.6 \mathrm{mmol})$ was dissolved in dichloromethane $(20 \mathrm{~mL})$ and cooled to $-78{ }^{\circ} \mathrm{C}$. DMSO $(5.52 \mathrm{~mL}, 77.7 \mathrm{mmol})$, dissolved in dichloromethane $(15 \mathrm{~mL})$, was added dropwise. After stirring at $-78{ }^{\circ} \mathrm{C}$ for $10 \mathrm{~min}$, a mixture of geraniol $(5.0 \mathrm{~g}, 32.4 \mathrm{mmol})$ and pyridine $(5.12 \mathrm{~g}, 64.8 \mathrm{mmmol})$ in dichloromethane $(20 \mathrm{~mL})$ was added dropwise. The reaction mixture was stirred at $-78{ }^{\circ} \mathrm{C}$ for $15 \mathrm{~min}$, and after addition of triethylamine $(22.4 \mathrm{~mL}, 0.16 \mathrm{~mol})$ the reaction temperature was allowed to rise to $25^{\circ} \mathrm{C}$. The mixture was then acidified to $\mathrm{pH} 4$ with $6 \mathrm{M}$ hydrochloric acid. The aqueous phase was extracted with dichloromethane $(50 \mathrm{~mL})$. The combined organic phase was dried $\left(\mathrm{Na}_{2} \mathrm{SO}_{4}\right)$ and concentrated. Flash chromatography (petroleum ether/ethyl acetate 7:1) provided geranial 9 $(4.56 \mathrm{~g}, 84 \%)$ as a yellow oil. $\mathrm{R}_{f}=0.22$ (petroleum ether/ethyl acetate 10:1). ${ }^{1} \mathrm{H}$ NMR $\left(300 \mathrm{MHz}, \mathrm{CDCl}_{3}\right): \delta 9.97(\mathrm{~d}, J=8.0 \mathrm{~Hz}, 1 \mathrm{H}), 5.90-5.84(\mathrm{~m}, 1 \mathrm{H}), 5.09-5.01(\mathrm{~m}, 1 \mathrm{H}), 2.23-2.17$ $(\mathrm{m}, 4 \mathrm{H}), 2.16(\mathrm{~s}, 3 \mathrm{H}), 1.67(\mathrm{~s}, 3 \mathrm{H}), 1.59(\mathrm{~s}, 3 \mathrm{H}) ;{ }^{13} \mathrm{C} \mathrm{NMR}\left(75.5 \mathrm{MHz}, \mathrm{CDCl}_{3}\right): \delta 191.1,163.7$, $132.7,127.3,122.4,40.6,25.7,25.6,17.8,17.6$.

Dimethyl (3E)-2-hydroxy-4,8-dimethylnona-3,7-dienylphosphonate (10). ${ }^{30}$ To a solution of dimethyl methylphosphonate $(2.4 \mathrm{~g}, 19.7 \mathrm{mmol})$ in THF $(40 \mathrm{~mL})$ at $-78{ }^{\circ} \mathrm{C}$ was added dropwise a solution of $n$-BuLi (12.3 mL, 15\% solution in THF, $19.7 \mathrm{mmol})$. Then, the mixture was stirred at $-78{ }^{\circ} \mathrm{C}$ for $20 \mathrm{~min}$, and a solution of geranial $9(3.0 \mathrm{~g}, 19.7 \mathrm{mmol})$ in THF $(10 \mathrm{~mL})$ was added dropwise at $-78{ }^{\circ} \mathrm{C}$. The reaction mixture was stirred for $2 \mathrm{~h}$ while warming up. The reaction was quenched by the addition of saturated aqueous ammonium chloride solution. The aqueous phase was extracted with ether $(2 \times 30 \mathrm{~mL})$, and the combined organic phase was dried $\left(\mathrm{Na}_{2} \mathrm{SO}_{4}\right)$ and concentrated. Flash chromatography (chloroform/methanol 90:10) provided $\mathbf{1 0}(3.82 \mathrm{~g}, 70 \%)$ as a yellow oil. $\mathrm{R}_{f}=0.65$ (chloroform/methanol 90:10). ${ }^{1} \mathrm{H} \mathrm{NMR}\left(400 \mathrm{MHz}, \mathrm{CDCl}_{3}\right): \delta 5.24(\mathrm{dd}$, $J=1.2,8.6 \mathrm{~Hz}, 1 \mathrm{H}), 5.07(\mathrm{tt}, J=1.2,7.0 \mathrm{~Hz}, 1 \mathrm{H}), 4.82-4.75(\mathrm{~m}, 1 \mathrm{H}), 3.78(\mathrm{~d}, J=3.1 \mathrm{~Hz}, 3 \mathrm{H})$, $3.75(\mathrm{~d}, J=3.5 \mathrm{~Hz}, 3 \mathrm{H}), 3.10(\mathrm{~d}, J=2.7 \mathrm{~Hz}, 1 \mathrm{H}), 2.17-1.87(\mathrm{~m}, 6 \mathrm{H}), 1.69(\mathrm{~d}, J=1.1 \mathrm{~Hz}, 3 \mathrm{H})$, $1.68(\mathrm{~s}, 3 \mathrm{H}), 1.59(\mathrm{~s}, 3 \mathrm{H}) ;{ }^{13} \mathrm{C} \mathrm{NMR}\left(75.5 \mathrm{MHz}, \mathrm{CDCl}_{3}\right): \delta 138.6,131.6,123.6(2 \times), 63.56$, 52.4, $39.4(2 \times), 26.4,25.7,17.8,16.7$. MS (EI): $m / z(\%) 276(1)[\mathrm{M}]^{+}, 258(20)\left[\mathrm{M}-\mathrm{H}_{2} \mathrm{O}\right]^{+}, 243$ (30), 215 (60), 202 (50), 189 (58), 151 (73), 133 (77), 124 (100), 109 (90), 105 (78), 94 (76), 79 (83), 69 (81), 55 (57). IR (film): $\widetilde{v} 3370$ (bs), 2954, 2916, 2852, 1739, 1669 (sh), 1652 (w), $1447,1375,1243,1185,1035,843,823,754 \mathrm{~cm}^{-1}$. 
Ethyl (4E)-5,9-dimethyldeca-4,8-dienoate (11). To a solution of trans-geraniol (5.3 $\mathrm{mL}$, $30 \mathrm{mmol})$ in ether $(25 \mathrm{~mL})$ at $-20{ }^{\circ} \mathrm{C}$ was added a solution of phosphorus tribromide $(1.4 \mathrm{~mL}$, $15 \mathrm{mmol})$ in ether $(15 \mathrm{~mL})$ within $10 \mathrm{~min}$, and the reaction mixture was stirred for $4 \mathrm{~h}$. The reaction was quenched with water, extracted with petroleum ether, washed in turn with water, saturated aqueous $\mathrm{NaHCO}_{3}$, and brine. The organic layer was dried $\left(\mathrm{MgSO}_{4}\right)$ and evaporated at $30{ }^{\circ} \mathrm{C}$ to provide $(E)$-geranyl bromide $(6.4 \mathrm{~g}, 99 \%)$ of as a labile yellow liquid.

To a suspension of $\mathrm{NaH}$ (1.44 $\mathrm{g}$ of $60 \%$ suspension in mineral oil, $60 \mathrm{mmol})$ in dry THF $(150 \mathrm{~mL})$ under argon was slowly added diethyl malonate $(9.14 \mathrm{~mL}, 60 \mathrm{mmol})$ at room temperature. The resulting solution was stirred for $30 \mathrm{~min}$, and a solution of geranyl bromide (4.24 g, $19.6 \mathrm{mmol})$ in THF $(10 \mathrm{~mL})$ was added. After stirring for $6 \mathrm{~h}$ the reaction mixture was quenched with saturated aqueous ammonium chloride. After addition of ether $(300 \mathrm{~mL})$ the organic layer was separated and washed with brine $(2 \times 100 \mathrm{~mL})$, dried $\left(\mathrm{MgSO}_{4}\right)$, evaporated, and the bulk of the diethyl malonate removed by Kugelrohr distillation in high vacuum to afford the crude product as residue $(7.90 \mathrm{~g}$, max. $19.6 \mathrm{mmol})$.

A mixture of crude diester $(7.90 \mathrm{~g}$, max. $19.6 \mathrm{mmol})$, water $(0.45 \mathrm{~mL}, 25 \mathrm{mmol})$, and lithium chloride $(2.11 \mathrm{~g}, 50 \mathrm{mmol})$ in DMSO $(40 \mathrm{~mL})$ was heated at reflux for 4 hours. After cooling, the reaction mixture was extracted with ether/petroleum ether $(1: 1,300 \mathrm{~mL})$. The extract was washed with water $(5 \times 50 \mathrm{~mL})$ and brine $(5 \times 50 \mathrm{~mL})$, dried over $\mathrm{MgSO}_{4}$, evaporated to yield ester $11(4.0 \mathrm{~g})$ as yellow oil. The purity (91\%) of the compound was checked by GC MS. The compound was used without purification for the next reaction. MS (EI): m/z (\%) 224 (2) [M] $]^{+}, 209$ (1) $\left[\mathrm{M}-\mathrm{CH}_{3}\right]^{+}, 155$ (14), 135 (57), 113 (62), 109 (86), 93 (33), 85 (73), 81 (90), 69 (100), 67 (72).

(6E)-10-Bromo-2,6-dimethyldeca-2,6-diene (12). To a solution of ester 11 (4.00 g, $17.8 \mathrm{mmol})$ in dry ether $(65 \mathrm{~mL})$ at $0{ }^{\circ} \mathrm{C}$ was added portionwise $\mathrm{LAH}(0.68 \mathrm{~g}, 17.8 \mathrm{mmol})$, and the mixture was stirred at room temperature for $3 \mathrm{~h}$. After cooling to $0{ }^{\circ} \mathrm{C}$, the reaction was quenched with water $(7 \mathrm{~mL})$, followed by $\mathrm{NaOH}(15 \%, 7 \mathrm{~mL})$, and the mixture was stirred for $15 \mathrm{~min}$. More water $(21 \mathrm{~mL})$ was added, stirring was continued for $30 \mathrm{~min}$ and $\mathrm{Na}_{2} \mathrm{SO}_{4}$ was added. The mixture was filtered through Celite, the filter cake was extracted with diethyl ether several times, the filtrates were combined, and the solvents were evaporated to give the alcohol $(3.1 \mathrm{~g} .96 \%)$ as a colorless oil. MS (EI): m/z (\%) 182 (3) [M] $]^{+}, 167$ (5) [M- $\left.\mathrm{CH}_{3}\right]^{+}, 149$ (22), 138 (98), 123 (68), 109 (46), 81 (97), 79 (99), 64 (100).

To a stirred solution of the alcohol $(3.1 \mathrm{~g}, 17.0 \mathrm{mmol})$ in dichloromethane $(40 \mathrm{~mL})$ was added triethylamine $(4.8 \mathrm{~mL}, 35.2 \mathrm{mmol})$ followed by dropwise addition of methanesulfonyl chloride $(1.9 \mathrm{~mL}, 19.3 \mathrm{mmol})$ at $0{ }^{\circ} \mathrm{C}$ within $15 \mathrm{~min}$. After stirring at $0{ }^{\circ} \mathrm{C}$ for $1.5 \mathrm{~h}$, the reaction mixture was diluted with dichloromethane, washed rapidly with hydrochloric acid $(10 \%, 40 \mathrm{~mL})$, saturated $\mathrm{NaHCO}_{3}(40 \mathrm{~mL})$, and brine $(40 \mathrm{~mL})$. The organic phase was dried $\left(\mathrm{MgSO}_{4}\right)$ and evaporated to produce the crude mesylate $(4.4 \mathrm{~g}, 99 \%)$ as a colorless oil. MS (EI): $\mathrm{m} / \mathrm{z}$ (\%) 260 (1) $[\mathrm{M}]^{+}, 245$ (4) $\left[\mathrm{M}-\mathrm{CH}_{3}\right]^{+}, 217$ (49), 149 (39), 121 (53), 107 (44), 93 (99), 79 (100), 67 (99).

The addition of anhydrous lithium bromide (4.6 g, $52.5 \mathrm{mmol})$ to a solution of the mesylate $(4.4 \mathrm{~g}$, $16.9 \mathrm{mmol})$ in dry THF $(30 \mathrm{~mL})$ at room temperature resulted in a mild exothermic reaction. The resulting suspension was stirred at room temperature for $23 \mathrm{~h}$, and after dilution with ether the 
organic phase was washed with water $(2 \times 30 \mathrm{~mL})$ and brine $(30 \mathrm{~mL})$, dried $\left(\mathrm{MgSO}_{4}\right)$ and evaporated to provide crude bromide $12(4.0 \mathrm{~g}, 93 \%)$ as a pale yellow liquid. The crude product 12 without purification was immediately used for the next step. MS (EI): $m / z$ (\%) 244 (3) [M] $]^{+}$, 229 (4) $\left[\mathrm{M}-\mathrm{CH}_{3}\right]^{+}, 201$ (40), 175 (13), 123 (52), 109 (37), 95 (59), 81 (39), 67 (100).

Diethyl (4E)-5,9-dimethyldeca-4,8-dienylphosphonate (13). A mixture of bromide 12 (4.0 g, $16.3 \mathrm{mmol})$ and triethyl phosphite $(54 \mathrm{~mL}, 326 \mathrm{mmol})$ was stirred under argon at $150{ }^{\circ} \mathrm{C}$ for $20 \mathrm{~h}$. While cooling to room temperature, triethyl phosphite was removed in high vacuum. The crude product was purified by flash chromatography (ethyl acetate/petroleum ether 1:1) to give $\mathbf{1 3}$ (4.1 g, 83 ) as a pale yellow oil. $\mathrm{R}_{f}=0.53$ (ethyl acetate). ${ }^{1} \mathrm{H} \mathrm{NMR}\left(300 \mathrm{MHz}, \mathrm{CDCl}_{3}\right): \delta 5.10-5.05(\mathrm{~m}$, 2H), 4.15-4.03 (m, 6H), 2.11-1 .95 (m, 6H), 1.78-1.62 (m, 2H), $1.68(\mathrm{~d}, J=1.3 \mathrm{~Hz}, 3 \mathrm{H}), 1.60$ $(\mathrm{s}, 6 \mathrm{H}), 1.32(\mathrm{t}, J=7.1 \mathrm{~Hz}, 6 \mathrm{H}) ;{ }^{13} \mathrm{C} \mathrm{NMR}\left(75.5 \mathrm{MHz}, \mathrm{CDCl}_{3}\right):=136.2,131.2,124.0,122.89$, $61.3(\mathrm{~d}, J=6.8 \mathrm{~Hz}), 39.7,28.6(\mathrm{~d}, J=17.4 \mathrm{~Hz}), 26.6,26.1,25.7,24.2,22.6(\mathrm{~d}, J=5.3 \mathrm{~Hz}), 17.7$, $16.6(\mathrm{~d}, J=5.3 \mathrm{~Hz}), 16.1 ;{ }^{31} \mathrm{P}\left(161.9 \mathrm{MHz}, \mathrm{CDCl}_{3}\right): \delta 33.3(\mathrm{~s}) . \mathrm{MS}(\mathrm{EI}): \mathrm{m} / \mathrm{z}(\%) 302(6)[\mathrm{M}]^{+}$, 259 (19), 233 (22), 205 (17), 177 (20), 165 (24), 152 (54), 125 (80), 109 (32), 95 (100), 81 (23), 69 (26).

Ethyl (4E)-5,9-dimethyldeca-4,8-dienylphosphonochloridoate (14). A solution of diester 13 $(2.7 \mathrm{~g}, 9.0 \mathrm{mmol})$ in methanol $(40 \mathrm{~mL})$ was treated with $1 \mathrm{M}$ aqueous potassium hydroxide $(40 \mathrm{~mL})$ and heated at $65{ }^{\circ} \mathrm{C}$. The reaction course was monitored by ${ }^{31} \mathrm{P} \mathrm{NMR}$. After $9 \mathrm{~h}$ the $\mathrm{pH}$ was adjusted to 6.5 , and methanol was evaporated. The aqueous solution was acidified with $10 \%$ hydrochloric acid and extracted with ethyl acetate $(3 \times 50 \mathrm{~mL})$. The organic layer was washed in turn with water and brine, dried $\left(\mathrm{MgSO}_{4}\right)$, and evaporated to provide the monoacid $(2.4 \mathrm{~g})$ as a pale yellow liquid; the purity ( $>83 \%$, some heat decomposition) was checked by GC-MS. $\mathrm{R}_{f}=$ 0.04 (ethyl acetate). ${ }^{31} \mathrm{P}$ NMR (161.9 MHz, $\mathrm{CDCl}_{3}$ ): $\delta 27.6$ (s). MS (ESI, negative mode): $\mathrm{m} / \mathrm{z}$ $273[\mathrm{M}-\mathrm{H}]^{-}$.

To a stirred solution of the monoacid $(2.9 \mathrm{~g}, 10.8 \mathrm{mmol})$ in dichloromethane $(10 \mathrm{~mL})$ was added under argon $\mathrm{N}, \mathrm{N}$-dimethyltrimethylsilylamine $(1.4 \mathrm{~mL}, 21.8 \mathrm{mmol})$. The mixture was stirred at room temperature for $2 \mathrm{~h}$. The solvent was evaporated, the residue was dissolved in benzene $(10 \mathrm{~mL})$, and the solvent was evaporated under vacuum for $30 \mathrm{~min}$. The residue was dissolved in dichloromethane $(8 \mathrm{~mL})$ containing 4 drops of DMF, and oxalyl chloride $(1.5 \mathrm{~mL}, 18 \mathrm{mmol})$ was added under argon at $0{ }^{\circ} \mathrm{C}$ within $10 \mathrm{~min}$. The solution was stirred at $0{ }^{\circ} \mathrm{C}$ for $75 \mathrm{~min}$ and then at room temperature for $45 \mathrm{~min}$. After evaporation of the solvent the residue was dissolved in benzene, which in turn, was evaporated under high vacuum to give the unstable acid chloride $\mathbf{1 4}$ $(3.15 \mathrm{~g}, 99 \%)$ as a labile orange oil that was immediately used without purification for the C-P coupling reaction.

Diethyl [[(4E)-5,9-dimethyldeca-4,8-dienyl](ethoxy)phosphoryl](difluoro)methylphosphonate (16). To a solution of LDA $(1.5 \mathrm{~g}, 14.4 \mathrm{mmol})$ in THF $(20 \mathrm{~mL})$ was added dropwise a solution of diethyl difluoromethylphosphonate $15(2.32 \mathrm{~g}, 12.0 \mathrm{mmol})$ in THF $(10 \mathrm{~mL})$ under argon at $-78{ }^{\circ} \mathrm{C}$ within $10 \mathrm{~min}$. The pale yellow solution was stirred at $-78{ }^{\circ} \mathrm{C}$ for $30 \mathrm{~min}$, and phosphonochloridoate 14 (3.2 g, $10.8 \mathrm{mmol})$, dissolved in THF (10 mL), was added over a period of $10 \mathrm{~min}$. The solution was maintained at $-78^{\circ} \mathrm{C}$ for $5 \mathrm{~h}$, and the reaction was quenched 
with acetic acid $(1.2 \mathrm{~mL})$ dissolved in ether $(16 \mathrm{~mL})$. The mixture was allowed to warm to room temperature and was partitioned between ether and $10 \% \mathrm{HCl}$; the ether layer was washed with water and saturated $\mathrm{NaHCO}_{3}$. The combined aqueous layer was extracted with dichloromethane $(2 \times 40 \mathrm{~mL})$. The combined organic phase was dried $\left(\mathrm{Na}_{2} \mathrm{SO}_{4}\right)$ and evaporated to provide an orange colored oil, which was subjected to flash chromatography (toluene/ethyl acetate/ petroleum ether 1:60:90) to give $16\left(2.78 \mathrm{~g}, 58 \%\right.$ ) as a yellow liquid. $\mathrm{R}_{f}=0.37$ (petroleum ether/ethyl acetate 1:1). ${ }^{1} \mathrm{H}$ NMR $\left(400 \mathrm{MHz}, \mathrm{CDCl}_{3}\right): \delta 5.13-5.05(\mathrm{~m}, 2 \mathrm{H}), 4.41-4.32(\mathrm{~m}, 6 \mathrm{H})$, 2.15-1.96 (m, 8H), 1.82-1.65 (m, 2H), $1.68(\mathrm{~s}, 3 \mathrm{H}), 1.60(\mathrm{~s}, 6 \mathrm{H}), 1.42-1.35(\mathrm{~m}, 9 \mathrm{H}) ;{ }^{13} \mathrm{C}$ NMR $\left(100.6 \mathrm{MHz}, \mathrm{CDCl}_{3}\right): \delta 136.7,131.3,124.1,122.6,117.4$ (tdd, $\left.J=282,182,104 \mathrm{~Hz}\right), 65.3(\mathrm{~d}, J$ $=6.3 \mathrm{~Hz}), 65.2(\mathrm{~d}, J=6.3 \mathrm{~Hz}), 64.4(\mathrm{~d}, J=6.3 \mathrm{~Hz}), 39.6,28.6(\mathrm{~d}, J=16.4 \mathrm{~Hz}), 26.5,25.5,24.7$ $(\mathrm{d}, J=97.8 \mathrm{~Hz}), 20.3(\mathrm{~d}, J=5.5 \mathrm{~Hz}), 17.5,16.4(\mathrm{~d}, J=5.5 \mathrm{~Hz}), 16.3(\mathrm{~d}, J=3.9 \mathrm{~Hz}), 16.2$ '(d, $J$ $=5.5 \mathrm{~Hz}), 15.9 ;{ }^{31} \mathrm{P} \mathrm{NMR}\left(161.9 \mathrm{MHz}, \mathrm{CDCl}_{3}\right): \delta 41.1(\mathrm{ddd}, J=55.2,71.0,78.0 \mathrm{~Hz}), 4.5(\mathrm{td}, J=$ 55.2, 85.4 Hz); ${ }^{19} \mathrm{~F}$ NMR $\left(376.3 \mathrm{MHz}, \mathrm{CDCl}_{3}\right) \delta-122.4(\mathrm{ddd}, J=78.0,85.0,371.6 \mathrm{~Hz}),-124.1$ (ddd, $J=71.0,85.4,371.6$ Hz). MS (EI): m/z (\%) 444 (3) [M] $]^{+}, 188$ (42), 109 (46), 95 (100), 69 (46). (2E,6E)-3,7,11-Trimethyldodeca-2,6,10-trienyl acetate (17). ${ }^{21}$ Acetic anhydride $(0.73 \mathrm{~mL}$, $7.6 \mathrm{mmol})$ was added to a solution of E,E-farnesol $(1.0 \mathrm{~g}, 4.4 \mathrm{mmol})$ in pyridine $(0.71 \mathrm{~mL}$, $8.9 \mathrm{mmol})$. The mixture was stirred over night at room temperature and diluted with ether $(50 \mathrm{~mL})$. The organic layer was washed with water $(30 \mathrm{~mL}), 2 \mathrm{M}$ hydrochloric acid $(2 \times 30 \mathrm{~mL})$, water $(30 \mathrm{~mL})$, and brine $(30 \mathrm{~mL})$, dried $\left(\mathrm{Na}_{2} \mathrm{SO}_{4}\right)$, and concentrated. Flash chromatography (petroleum ether/ethyl acetate 10:1) provided $17(0.89 \mathrm{~g}, 75 \%)$ as a colorless oil. $\mathrm{R}_{f}=0.63$ (petroleum ether/ethyl acetate 10:1). ${ }^{1} \mathrm{H}$ NMR (300 MHz, $\left.\mathrm{CDCl}_{3}\right): \delta 5.39(\mathrm{~m}, 1 \mathrm{H}), 5.20(\mathrm{~m}, 2 \mathrm{H})$, $4.75(\mathrm{~d}, J=8.0 \mathrm{~Hz}, 2 \mathrm{H}), 2.02(\mathrm{~m}, 8 \mathrm{H}), 2.01(\mathrm{~s}, 3 \mathrm{H}), 1.72(\mathrm{~s}, 3 \mathrm{H}), 1.71(\mathrm{~s}, 3 \mathrm{H}), 1.70(\mathrm{~s}, 3 \mathrm{H}), 1.69$ $(\mathrm{s}, 3 \mathrm{H}) ;{ }^{13} \mathrm{C} \mathrm{NMR}\left(75.5 \mathrm{MHz}, \mathrm{CDCl}_{3}\right): \delta 171.1,138.7,138.6,133.9,122.5,121.9,121.7,62.9$, $40.5,40.2,25.3,24.3,24.0,19.3,17.4,17.2,16.9$.

(2E,6E)-10-Bromo-11-hydroxy-3,7,11-trimethyldodeca-2,6-dienyl acetate (18). ${ }^{21}$ To a stirred solution of $E$,E-farnesyl acetate $17(2.1 \mathrm{~g}, 7.9 \mathrm{mmol})$ in 1,2-dimethoxyethane $(16 \mathrm{~mL})$ and water $(10 \mathrm{~mL})$ at $0{ }^{\circ} \mathrm{C}$ was added within $30 \mathrm{~min}$ a solution of $N$-bromosuccinimide $(1.48 \mathrm{~g}, 8.3 \mathrm{mmol})$ in 1,2-dimethoxyethane $(25 \mathrm{~mL})$. The mixture was stirred at $0{ }^{\circ} \mathrm{C}$ for $4 \mathrm{~h}$ and was then poured into brine $(40 \mathrm{~mL})$ followed by extraction with ether $(3 \times 40 \mathrm{~mL})$. The combined organic layer was washed with brine $(40 \mathrm{~mL})$, dried $\left(\mathrm{Na}_{2} \mathrm{SO}_{4}\right)$ and concentrated in vacuo to give crude 18 $(2.82 \mathrm{~g})$ as a pale yellow oil. $\mathrm{R}_{f}=0.16$ (petroleum ether/ethyl acetate $\left.10: 1\right) .{ }^{1} \mathrm{H} \mathrm{NMR}(300 \mathrm{MHz}$, $\left.\mathrm{CDCl}_{3}\right): \delta 5.34(\mathrm{dt}, J=1.2,7.0 \mathrm{~Hz}, 1 \mathrm{H}), 5.19(\mathrm{dd}, J=5.9,6.8 \mathrm{~Hz}, 1 \mathrm{H}), 4.59(\mathrm{~d}, J=7.0 \mathrm{~Hz}, 2 \mathrm{H})$, $3.96(\mathrm{dd}, J=1.9,11.4 \mathrm{~Hz}, 1 \mathrm{H}), 2.35-2.28(\mathrm{~m}, 2 \mathrm{H}), 2.16-2.07(\mathrm{~m}, 2 \mathrm{H}), 2.05(\mathrm{~s}, 3 \mathrm{H}), 2.01-1.93$ $(\mathrm{m}, 1 \mathrm{H}), 1.84-1.73(\mathrm{~m}, 1 \mathrm{H}), 1.70(\mathrm{~s}, 3 \mathrm{H}), 1.60(\mathrm{~s}, 3 \mathrm{H}), 1.35(\mathrm{~s}, 3 \mathrm{H}), 1.34(\mathrm{~s}, 3 \mathrm{H}) ;{ }^{13} \mathrm{C}$ NMR $\left(75.5 \mathrm{MHz} \mathrm{CDCl}_{3}\right): \delta 170.9,141.8,133.4,125.2,118.3,70.6,61.4,39.4,38.1,32.0,26.6,26.2$, $25.9,21.1,16.5,15.9$.

(2E,6E)-9-(3,3-Dimethyloxiran-2-yl)-3,7-dimethylnona-2,6-dien-1-ol (19). ${ }^{21}$ Bromohydrin 18 $(0.35 \mathrm{~g}, 0.97 \mathrm{mmol})$ was dissolved in methanol $(10 \mathrm{~mL})$, and to the solution was added potassium carbonate $(0.40 \mathrm{~g}, 2.91 \mathrm{mmol})$. The mixture was stirred over night at room temperature, filtered through Celite, and the filtrate was concentrated in vacuo. The residue was 
diluted with brine $(10 \mathrm{~mL})$ and extracted with ether $(3 \times 10 \mathrm{~mL})$. The combined ether layer was washed with brine $(10 \mathrm{~mL})$, dried $\left(\mathrm{Na}_{2} \mathrm{SO}_{4}\right)$, and concentrated in vacuo to give $19(0.14 \mathrm{~g}, 63 \%)$ as a colorless oil. $\mathrm{R}_{f}=0.49$ (petroleum ether/ethyl acetate $\left.2: 1\right) .{ }^{1} \mathrm{H}$ NMR $\left(400 \mathrm{MHz}, \mathrm{CDCl}_{3}\right): \delta$ $5.40(\mathrm{t}, J=7.0 \mathrm{~Hz}, 1 \mathrm{H}), 5.15(\mathrm{t}, J=7.0 \mathrm{~Hz}, 1 \mathrm{H}), 4.13(\mathrm{~d}, J=7.0 \mathrm{~Hz}, 2 \mathrm{H}), 2.70(\mathrm{t}, J=6.0 \mathrm{~Hz}$, $1 \mathrm{H}), 2.15-2.02(\mathrm{~m}, 6 \mathrm{H}), 1.67(\mathrm{~s}, 3 \mathrm{H}), 1.62(\mathrm{~s}, 3 \mathrm{H}), 1.55-1.52(\mathrm{~m}, 2 \mathrm{H}), 1.30(\mathrm{~s}, 3 \mathrm{H}), 1.26(\mathrm{~s}, 3 \mathrm{H})$; ${ }^{13} \mathrm{C} \mathrm{NMR}\left(100 \mathrm{MHz}, \mathrm{CDCl}_{3}\right): \delta 139.41,134.49,124.71,123.79,64.53,59.55,58.80,39.80$, $36.74,27.68,26.57,25.31,19.25,16.70,16.45$.

(2E,6E)-3,7,11-Trimethyldodeca-2,6-diene-1,10,11-triol (20). ${ }^{22}$ To a stirred solution of epoxide $19(0.1 \mathrm{~g}, 0.4 \mathrm{mmol})$ in a mixture of water $(2.5 \mathrm{~mL})$ and THF $(5 \mathrm{~mL})$ were added 4 drops of $70 \%$ aqueous perchloric acid. After $4 \mathrm{~h}$ the mixture was extracted with ether $(3 \mathrm{x}$ $10 \mathrm{~mL})$, and the combined organic layer was washed with water $(10 \mathrm{~mL})$ and brine $(10 \mathrm{~mL})$, dried $\left(\mathrm{Na}_{2} \mathrm{SO}_{4}\right)$, and concentrated in vacuo to give $20(78 \mathrm{mg}, 73 \%)$ as a pale yellow oil. $\mathrm{R}_{f}=$ 0.16 (petroleum ether/ethyl acetate 1:1). ${ }^{1} \mathrm{H} \mathrm{NMR}\left(300 \mathrm{MHz}, \mathrm{CDCl}_{3}\right): \delta 5.38(\mathrm{dd}, J=5.5$, $6.8 \mathrm{~Hz}, 1 \mathrm{H}), 5.16(\mathrm{t}, J=6.1 \mathrm{~Hz}, 1 \mathrm{H}), 4.13(\mathrm{~d}, J=6.6 \mathrm{~Hz}, 2 \mathrm{H}), 3.36(\mathrm{dd}, J=1.9,10.4 \mathrm{~Hz}, 1 \mathrm{H})$, 2.39-2.28 (m, 2H), 2.22-2.04 (m, 4H), $1.64(\mathrm{~s}, 3 \mathrm{H}), 1.61$ (s, 3H), 1.46-1.39 (m, 1H), 1.37-1.32 $(\mathrm{m}, 1 \mathrm{H}), 1.17(\mathrm{~s}, 3 \mathrm{H}), 1.14(\mathrm{~s}, 3 \mathrm{H}) ;{ }^{13} \mathrm{C} \mathrm{NMR}\left(75 \mathrm{MHz}, \mathrm{CDCl}_{3}\right): \delta 138.6,134.9,125.0,124.0$, 77.6, 73.0, 59.3, 39.3, 36.6, 28.9, 26.4, 25.6, 23.3, 15.9, 15.8 .

(6E,10E)-12-Chloro-2,6,10-trimethyldodeca-6,10-diene-2,3-diol (21). $N$-Chlorosuccinimide $(0.08 \mathrm{~g}, 0.64 \mathrm{mmol})$ was dissolved in dichloromethane $(40 \mathrm{~mL})$ and cooled to $-30{ }^{\circ} \mathrm{C}$. To the cooled, well stirred, now heterogeneous mixture dimethyl sulfide $(51 \mu \mathrm{L}, 0.70 \mathrm{mmol})$ was added dropwise. The mixture was briefly allowed to warm to $0{ }^{\circ} \mathrm{C}$ before the temperature was lowered to $-40{ }^{\circ} \mathrm{C}$. A solution of the $20(0.15 \mathrm{~g}, 0.58 \mathrm{mmol})$ in dichloromethane $(5 \mathrm{~mL})$ was added through a syringe to the milky white suspension within $3 \mathrm{~min}$. The reaction was slowly $(1 \mathrm{~h})$ allowed to warm to $0{ }^{\circ} \mathrm{C}$ and maintained at this temperature for $1 \mathrm{~h}$. During this period, the mixture became a clear colorless solution. The ice bath was removed, and the mixture was stirred at room temperature for $15 \mathrm{~min}$ before it was poured into cold brine $(25 \mathrm{~mL})$ in a separatory funnel. The aqueous layer was extracted with pentane $(2 \times 20 \mathrm{~mL})$. To the combined organic layer was added pentane $(20 \mathrm{~mL})$, and this solution was washed with cold brine $(2 \times 10 \mathrm{~mL})$, dried $\left(\mathrm{Na}_{2} \mathrm{SO}_{4}\right)$, concentrated in vacuo to provide chloride $21(0.16 \mathrm{~g}, 98 \%)$ as a pale yellow oil. ${ }^{1} \mathrm{H}$ NMR $\left(300 \mathrm{MHz}, \mathrm{CDCl}_{3}\right): \delta 5.42(\mathrm{dt}, J=1.1,7.9 \mathrm{~Hz}, 1 \mathrm{H}), 5.15(\mathrm{dd}, J=1.4,6.9 \mathrm{~Hz}, 1 \mathrm{H}), 4.09$ $(\mathrm{d}, J=7.9 \mathrm{~Hz}, 2 \mathrm{H}), 3.34(\mathrm{dd}, J=1.9,10.4 \mathrm{~Hz}, 1 \mathrm{H}), 2.26-2.01(\mathrm{~m}, 6 \mathrm{H}), 1.72(\mathrm{~s}, 3 \mathrm{H}), 1.61$ (s, $3 \mathrm{H}), 1.58-1.54(\mathrm{~m}, 1 \mathrm{H}), 1.37-1.32(\mathrm{~m}, 1 \mathrm{H}), 1.19(\mathrm{~s}, 3 \mathrm{H}), 1.15(\mathrm{~s}, 3 \mathrm{H}) ;{ }^{13} \mathrm{C} \mathrm{NMR}(75 \mathrm{MHz}$, $\left.\mathrm{CDCl}_{3}\right): \delta 142.4,135.3,124.0,120.4,78.2,41.2,39.3,36.7,30.4,29.7,26.5,26 ., 23.3,16.1$.

Enzyme inhibition assay. The standard $1 \mathrm{mM}$ assay contained in a final volume of $100 \mu \mathrm{L}$ : $10 \mu \mathrm{L}$ of a $10 \mathrm{mM}$-hydroxybenzoate solution; $10 \mu \mathrm{L}$ organic soluble inhibitor in DMSO (blank, or $0.5 \mathrm{mM}$, or $1 \mathrm{mM}$, or $2 \mathrm{mM}$, or $5 \mathrm{mM}$, or $10 \mathrm{mM}$ solutions of potential inhibitors, obtained by a dilution series from a $10 \mathrm{mM}$ solution), or $10 \mu \mathrm{L}$ water soluble inhibitor in Tris/ $\mathrm{HCl}$ buffer $(\mathrm{pH}$ 7.8 , blank, or $0.5 \mathrm{mM}$, or $1 \mathrm{mM}$, or $2 \mathrm{mM}$, or $5 \mathrm{mM}$, or $10 \mathrm{mM}$ solutions of potential inhibitors, obtained by a dilution series from a $10 \mathrm{mM}$ solution); $10 \mu \mathrm{L}$ of a $0.05 \mathrm{M} \mathrm{MgCl}_{2}$ solution; $10 \mu \mathrm{L}$ 
of a $10 \mathrm{mM}$ solution of geranyl diphosphate and $50 \mu \mathrm{L}$ of enzyme ${ }^{23}$ in $50 \mathrm{mM}$ Tris/ $\mathrm{HCl}, 10 \mathrm{mM}$ DTT buffer, pH 7.8. Incubation was done under shaking at $37{ }^{\circ} \mathrm{C}$ for $2 \mathrm{~h}$. The reaction was quenched by the addition of $10 \mu \mathrm{L} 2 \%$ aqueous formic acid solution. Products were extracted with ethyl acetate $(0.5 \mathrm{~mL})$ containing $p$-hydroxybiphenyl $(50 \mu \mathrm{M})$ as internal HPLC-standard. Ethyl acetate was then removed in vacuo and the remainder was dissolved in methanol $(100 \mu \mathrm{L})$. The samples were then analyzed for the formation of GHB by HPLC.

\section{Acknowledgements}

The pALMU3 plasmid was kindly provided by Prof. L. Heide (Tübingen). We would like to thank Prof. M. Pietzsch and Dr. T. Hertel (Martin-Luther-Universität Halle-Wittenberg) for their support with optimizing fermentation, enzyme preparation, and for invaluable discussions. We thank the state of Saxony-Anhalt for support as part of the HWP-program.

\section{References}

1. (a) Poulter, C. D.; Rilling, H. C. Acc.Chem. Res. 1978, 11, 307. (b) Poulter, C. D.; Mash, E. A.; Argyle, J. C.; Muscio, O. J.; Rilling, H. C. J. Am. Chem. Soc. 1979, 101, 6761.

2. Ashby, M. N.; Edwards, P. A. J. Biol. Chem. 1990, 265, 13157.

3. Caillet, J.; Droogmans, L.; J. Bacteriol 1988, 170, 4147.

4. (a) Stöber, P.; Schelhaas, M.; Nägele, E.; Hagenbuch, P.; Rétey, J.; Waldmann, H. Bioorg. Med. Chem. 1997, 5, 75. (b) Mayer, M. P.; Prestwich, G. D.; Dolence, J. M.; Bond, P. D.; Wu, H. Y.; Poulter, C. D. Gene 1993, 132, 41.

5. Shineberg, B.; Yong, I. G. Biochemistry 1976, 15, 2754.

6. (a) Wessjohann, L.; Sontag, B. Angew. Chem. 1996, 108, 1821. Angew. Chem., Int. Ed. 1996, 35, 1697. (b) Wessjohann, L. A.; Sontag, B.; Dessoy, M. A. In Bioorganic Chemistry; Diederichsen, U.; Lindhorst, T. K.; Westermann, B.; Wessjohann, L. A., Eds.; Wiley-VCH: Weinheim, 1999; pp 79-88. (c) Wessjohann, L.; Sontag, B. GIT Labor-Fachzeitschrift 1998, 42, 229.

7. Singh, S. B.; Zink, D. L.; Liesch, J. M.; Goetz, M. A.; Jenkins, R. G.; Nallin-Omstead, M.; Silverman, K. C.; Bills, G. F.; Mosley, R. T.; Gibbs, J. B.; Albers-Schonberg, G.; Lingham, R. B. Tetrahedron 1993, 49, 5917.

8. Corey, E. J.; Volante, R. P. J. Am. Chem. Soc. 1976, 98, 1291.

9. McClard, R. W.; Fujita, T. S.; Stremler, K. E.; Poulter, C. D. J. Am. Chem. Soc. 1987, 109, 5544.

10. Stremler, K. E.; Poulter, C. D. J. Am. Chem. Soc. 1987, 109, 5542.

11. Holstein, S. A.; Cermak, D. M.; Wiemer, D. F.; Lewis, K.; Hohl, R. J. Bioorg. Med. Chem. 1998, 6, 687. 
12. Fulhorst, M.; Wessjohann, L. manuscript in preparation.

13. Kang, M. S.; Stemerick, D. M.; Zwolshen, J. H.; Harry,; Sunkara, P. S.; Harrison, B. L. Biochem. Biophys. Res. Com. 1995, 217, 245.

14. Biller, S. A.; Forster, C. Tetrahedron 1990, 46, 6645.

15. Cermak, D. M.; Wiemer, D. F.; Lewis, K.; Hohl, R. Bioorg. Med. Chem. 2000, 8, 2729.

16. Bhattacharya, A. K.; Thyagarajan, G. Chem. Rev. 1981, 81, 415.

17. Bhongle, N. N.; Notter, R. H.; Turcotte, J. G. Synth. Commun. 1987, 17, 1071.

18. Obayashi, M.; Ito, E.; Matsui, K.; Kondo, K. Tetrahedron Lett. 1982, 23, 2323.

19. van Tamelen, E. E.; Sharpless, K. B. Tetrahedron Lett. 1967, 2655.

20. Hanzlik, R. P. Org. Synth. 1977, 56, 112.

21. Sakai, T.; Mori, K. Agric. Biol. Chem. 1986, 50, 177.

22. Suzuki, Y.; Marumo, S. Tetrahedron Lett. 1972, 19, 1887.

23. Davisson, V. J.; Woodside, A. B.; Neal, T. R.; Stremler, K. E.; Muehlbacher, M.; Poulter, C. D. J. Org. Chem. 1986, 51, 4768.

24. (a) Heide, L.; Melzer, M.; Siebert, M.; Bechthold, A.; Schröder, J.; Severin, K. J. Bacteriol. 1993, 175, 5728. (b) Melzer, M.; Heide, L. Biochim. Biophys. Acta 1994, 1212, 93.

25. Khmelnitsky, Y. L.; Rich, J. O. Curr. Opin. Chem. Biol. 1999, 3, 47.

26. (a) Blachburn, G. M.; England, D. A.; Kolkmann, F. J. Chem. Soc., Chem. Commun. 1981, 930. (b) Blachburn, G. M.; Kent, D. E.; Kolkmann, F. J. Chem. Soc., Chem. Commun. 1981, 1188. (c) Blachburn, G. M.; Eckstein, F.; Kent, D. E.; Perree, T. D. Nucleosides Nucleotides 1985, 4, 165. (d) Phan, R. M.; Poulter, C. D. J. Org. Chem. 2001, 66, 6705.

27. Fulhorst, M. Prenyltransferases as Potential Biocatalysts. Doctoral Dissertation,: L. A. Wessjohann, Ed.; Martin-Luther-Universität Halle-Wittenberg: Halle (Saale), 2003.

28. Corey, E. J.; Desai, M. C. Tetrahedron Lett. 1985, 26, 3535.

29. (a) Biller, S. A.; Forster, C.; Gordon, E. M.; Harrity, T.; Scott, W. A.; Ciosek, C. P. J. Med. Chem. 1988, 31, 1869. (b) Fumoto, Y.; Eguchi, T.; Uno, H.; Ono, N. J. Org. Chem. 1999, 64, 6518.

30. Dessoy, M. A. Synthesis and Enzymatic Coupling of Prenyldiphosphates and Benzoates; Doctoral Dissertation, L. A. Wessjohann, Ed.; Martin-Luther-Universität: Halle-Wittenberg, Halle (Saale), 2003. 